\title{
Banka Tercihini Etkileyen Halkla Illişkiler Değişkenleri: Kurum İmajı Üzerine Bir Alan Araştırması
}

\author{
Ahmet Tarhan (Doç. Dr) \\ Selçuk Üniversitesi İletişim Fakültesi \\ tarhan@selcuk.edu.tr \\ ORCID: 0000-0003-4074-1914 \\ Salih Gürbüz (Dr. Öğr. Üyesi) \\ Necmettin Erbakan Üniversitesi Güzel Sanatlar Fakültesi \\ gurbuzsalih@hotmail.com \\ ORCID: 0000-0002-5690-8136
}

Başvuru Tarihi: 01.10.2019

Yayına Kabul Tarihi: 04.11.2019

Yayınlanma Tarihi: 24.01.2020

DOI: http://10.17680/erciyesiletisim.628039

\section{Öz}

İnsanlar tarafından inşa edilen ve ancak insanların desteği ile var olabilen kurumlar için olumlu bir imajla algılanma önemli bir kaygıdır. Kurumsal imaj kurumlar için ihmal edilemez bir yaşamsal uzuv gibidir. Kurumsal varlığın devamı olumlu imajın sağlanması ve korunması ile mümkündür. Kurumsal imaj kurumun görsel unsurları, kültürü, felsefesi, davranışı, iletişimi, kurumsal sorumluluk faaliyetleri gibi geniş bileşenlerden oluşmaktadır. Kurumların hedef kitleleri nezdinde oluşturduğu algıların toplamına karşılık gelen kurumsal imaj, kurumsal tercihleri etkileyebilmektedir. Günümüzün bilinçli tüketicileri olan bireyler çeşitli ihtiyaçlarını karşılarken kurumların imajlarını dikkate almaktadır. Küresel rekabet koşullarından en çok etkilenen kurumlar arasında yer alan bankalar da bireylerinin günlük yaşamında önemli yere sahiptir. $\mathrm{Bu}$ açıdan bankalar da mevcut ve potansiyel müşterilerini korumak için kurumsal imajlarını olumlu yönde etkileyecek girişimlerde bulunmaktadır. Bu faaliyetler kurumsal sosyal sorumluluk, kurumsal iletişim, kurumsal kimlik, kurumsal davranış gibi kurumun imajını etkileyen unsurlara yönelik gerçekleştirilmektedir. Bu çalışma; halkla ilişkiler literatüründe eksikliği görülen doğrudan finans kurumlarının kurumsal imajlarına yönelik belirleyicilerin neler olduğu konusunu araştırmayı amaçlamıștır. Buna yönelik olarak Konya il merkezinde 18 yaş üzeri 558 katılımcı ile yüz yüze anket tekniği kullanılarak Nisan-Haziran 2019 tarihlerinde bir alan araștırması gerçekleștirilmiştir. Araştırma Konya il merkezindeki 18 yaş üzeri bireylerle sınırlandırılmıştır. Ancak bu araştırma banka tercihlerini belirleyen kurumsal imaj belirleyicilerine yönelik yapılan araştırmaların neredeyse çok sınırlı olmasından dolayı önemli görülmektedir. Çalışmanın bulgularına göre; 18-25 yaş grubundaki çoğunluğu üniversite öğrencisi olan, kredi kartı olan ve online bankacılık hizmetleri alan katılımcılar banka tercihlerinde güvenlik değişkenini en çok önemseyenler olmuştur. Ancak kurumsal imajı belirleyen kurumsal davranış, kurumsal iletişim, kurumsal görünüm (görsel kimlik) ve sosyal sorumluluk değişkenlerine yönelik yargılarda ayrıca tüm katılımcılar tarafından önemsenmektedir. Bu sonuçlara göre bankalar kurumsal imajlarına yönelik üretecekleri politikalarda güvenlik başta olmak üzere, diğer kurumsal imaj belirleyicilerine de oldukça önem vermeleri gerektiği değerlendirilmiştir.

Anahtar Kelimeler: İmaj, Kurumsal İmaj, Halkla İlişkiler, Banka İmajı. 
Research Article

\title{
Public Relations Factors Affecting Bank Preferences: A Field Research On Corporate Image
}

\author{
Ahmet Tarhan (Assoc. Prof. Dr.) \\ Selçuk University Faculty of Communication \\ tarhan@selcuk.edu.tr \\ ORCID: 0000-0003-4074-1914 \\ Salih Gürbüz (Asst. Prof. Dr.) \\ Necmettin Erbakan University Faculty of Fine Arts \\ gurbuzsalih@hotmail.com \\ ORCID: 0000-0002-5690-8136
}

Date Received: 01.10.2019

Date Accepted: 04.11.2019

Date Published: 24.01.2020

DOI: http://10.17680/erciyesiletisim.628039

\begin{abstract}
Perceived with a positive image is an important concern for the organizations that are built by people and can only exist with the support of people. Corporate image is a vital part of the organization that cannot be neglected. The continuation of the corporate asset is possible by achieving and maintaining a positive image. Corporate image consists of a wide range of components such as visual elements, corporate philosophy, corporate behavior, corporate communication and corporate social responsibility activities. The corporate image, which is the total perceptions created by the target groups of the corporations, may affect the corporate preferences. Individuals, who are today's conscious consumers, pay more attention to the images of corporations while suppliying their various needs. Banks, which are among the corporations most affected by the global competition conditions, have an important place in the daily life of their target audiences. In this respect, banks attempt various initiatives, which would positively affect their corporate image, to protect their existing and potential customers. These activities are carried out for the factors, which affect the corporate image, such as corporate social responsibility, corporate communication, corporate identity and corporate behavior. The aim of this study is to investigate the determinants of the corporate image of financial institutions which are lacking in public relations literature. For this purpose, a field survey was conducted in Konya city center between the months of April and June 2019 by using face-to-face survey technique with 558 participants over 18 years of age. The study was limited to individuals over the age of 18 in Konya city center. However, this research is considered important because of the limited number of studies conducted on corporate image determinants that determine bank preferences. As a result, participants in the 18-25 age group, most of them university students, who have credit cards and who receive online banking services, give more importance to the security factor in bank preferences. However, corporate behavior, corporate communication, visual identity and social responsibility factors that determine corporate image are also considered by all participants. According to these results, it can be stated that banks should give importance especially security factor and other corporate image determinants in their policies for corporate image.
\end{abstract}

Keywords: Image, Corporate Image, Public Relations, Banks' Image. 


\section{Giriş}

"Değişimin" dahi her geçen gün daha hızlı değiştiği günümüzde, bireyler gibi kurumlar da değişimde yașanan bu hız ve çeșitlilikten payına düșeni almaktadır. Kurumların bireyler üzerinde en etkili olduğu günümüz dünyasında, kurumları birey ve toplum üzerinde bu şekilde etkili hale getiren şüphesiz bireylerin sınırı sürekli değişim gösteren beklenti ve ihtiyaçlarıdır. Bireylerin bu beklenti ve ihtiyaçlarına karşılık verme gücü kurumları sürekli yeni olanaklardan yararlanma gerekliliğini ortaya çıkarmaktadır. Halkla ilişkilerin uygulamaları da bu gerekliliğin karşılanmasında kurumların ihtiyaçlarına yanit vermektedir.

Kurumların hedef kitleleri nezdinde diğerleri arasında farklılaşmasını sağlayacak faktörlerin gerçekleşmesi ise sosyal sorumluluk, sponsorluk, olumlu imaj ve itibar oluşturma, farklılık sağlayacak ayırt edici bir kurumsal kimlik oluşturma çabaları vb. uygulamalar halkla ilişkiler kapsamında gerçekleştirilebilmektedir. Bu gelişim ve değişmeler tüm sektörlerde olduğu gibi finans kurumları olan bankaları da etkilemektedir. Bankalar da tüm paydaşlarını memnun edecek, onların gözünde olumlu bir imaj ve itibarla algılanabilecek faaliyetlere önem vermektedir. Bu faaliyetler bankaların çeşitli paydaşlarına yönelik medyada reklamlarla yer almasından, sosyal sorumluluk ve sponsorluk gibi toplum nezdinde topluma yararlı kurumlar olarak görünme arzusuna olanak sağlayan faaliyetlere kadar çok çeşitli çabalarla kendini göstermektedir.

Ayrıca paydaşlara yönelik yapılan birebir iletişimin ön planda tutulduğu hizmetler de bankalar tarafından öncelikli hale gelmektedir. Bu birebir iletişim faaliyetleri kimi zaman müșterilerin doğrudan bankadan hizmet almaya gittiğinde banka personelinin her birinin davranışı ve tutumları ile olabilirken, kimi zamanda günümüzün en önemli iletişim ihtiyaçlarına yanıt veren internet ve mobil bankacılık hizmetlerinde de karşılık bulabilmektedir. Müşteriler tüm ihtiyaçlarının karşılanmasında olduğu gibi finansal hizmet alımlarında da hıza ve kolay ulaşılabilirliğe önem verdiği genel bir gerçektir. Bu anlamda bankalar da bu gerçekliği daha çok paydaşa yansıtmak için gelişen iletişim teknolojilerinin her çeşidini hedef kitlelerine sunabilme amacıyla değişim ve gelişim için teknoloji içerikli uygulamalar üretme zorunluluğu içindedir.

Paydaşlar nezdinde olumlu bir imajla algılanabilmek adına kurumların tercih ettiği ve yürüttüğü iletişim, tutum ve davranışları kadar kurumların diğerlerinden ayırt edilebilmesinde önemli görülen kurumsal farklılığın ifade biçimi olarak tanımlanabilecek olan kurumların görünümü de büyük önem taşımaktadır. Kurumların görünümü de kurumların kurumsal anlamda kimlik çalışmaları neticesinde ortaya çıkan bir boyuttur.

Tüm bunların yanında güvenlik de bankaların hem bireyler hem de kurumlar açısından tercih edilmesi bakımından en önemli belirleyici unsurlardandır. Bu sebeple finansal kurumlarda güvenlik hususunda paydaşlarını fazlasıyla tatmin edici çabaları ortaya koyma mecburiyetindedir. Bu bağlamda bankaların aldığı ya da alacağı ve teminatını verdiği güvenlik tedbirleri bireyler için hayati önem arz etmektedir. Bu sebeple güvenlik değişkeni, finansal durumlarda bankaların tercih edilmesinde önemli bir unsur olarak ifade edilebilir.

Bu çalışmada da bankaların paydaşları arasında en önemli konumda bulunan müşterilerine yönelik hangi faaliyetlerle nasıl bir algı oluşturduğu araştırılmak istenmiştir. Bu bilimsel merak neticesinde Konya ili örneğinde nicel veri toplama teknikleri arasında yer alan anket tekniği ile bankaların imajını oluşturan unsurların neler olduğu ve bu unsurların 
arasında hangilerinin müşteriler tarafından daha çok önemsendiği belirlenmeye çalışılmıştır. Çalışma kapsamında kurumsal imaj, kurumsal kimlik, kurumsal sosyal sorumluluk ve kurumsal iletişim kavramları alan yazın incelemesi ile teorik olarak ifade edilmiş ve alan yazın incelemesi sonucunda oluşturulan ve gerçekleștirilen anketin bulguları değerlendirilmiştir.

\section{Bankalarda Halkla İlişkilerin Yeri}

Batı ülkelerinde özellikle Amerika'da 1930'lu yıllarla birlikte, iş hayatında halkla daha iyi ilişkiler kurma gereği hissedilmiş ve bankacılık sektöründe de bu benimsenmiştir (Yavuz, 1972, s.50). Türkiye'de ise 1960'lardan sonra yavaş yavaş güçlenen özel kuruluşların giderek örgütlenmeye başlayan toplumun çeşitli katmanlarına özellikle de tüketicilere karşı kendilerini ifade edebilmeleri için halkla ilişkiler uygulamalarından yararlandıkları görülmektedir (Kazancl, 2013, s.13). Özellikle 1969 yılından sonra büyük holdinglerin ve bazı bankaların halkla ilişkilerin önemini kabul etmeleri (Peltekoğlu, 2014, s.98), halkla ilişkilerin kuruluş içerisinde bir yönetim fonksiyonu olarak değerlendirilmesinin de ilk adımları olmuştur.

Bankacılık halkla ilişkiler faaliyetlerinin en gelişkin olduğu sektörlerden birisidir ve teknolojik gelişmeleri anında uygulamaya sokan bankacılık sektörü, değişime öncülük etmektedir. Halkla ilişkiler faaliyetlerinin yoğunluğuna karşın, bu faaliyetlerin önemi hiçbir zaman azalmamakta ve her geçen gün daha da fazla önem kazanmaktadır (Özdemir, 2012, s.5).

Kişilerin tasarruflarını güvence altına alan kuruluşlar olarak bankaların diğer işletmelere göre daha çok halkla ilişkilere ihtiyacı vardır. Halkı ikna etmek, güvenilir imaj yaratmak, gelişen teknoloji, çeşitlenen hedef kitle ve sıkı rekabet etkin halkla ilişkiler çalışmalarını bankalar için zorunlu kılmaktadır. Hizmet sektöründe yer alan bankaların fark yarattıkları her ürün rakipleri tarafından kolayca taklit edilebilmektedir. Bu nedenle, bankalar taklit edilmenin önüne geçmek, bankayı rakiplerinden farklılaştırmak, hizmet ve müşteri ilişkilerinin kalitesini artırmak amacıyla örgüt içi ve örgüt dışı yapılan başarılı ve sürekli halkla ilişkiler çalışmalarına başvurmaktadırlar (İraz, Çetin ve Karakoyun, 2012, s.214).

Bankacıllk sektöründe hedef kitlenin sadece halk ve müşterilerden meydana geldiği yönünde genel bir kanı olmasına karşın; gerçekte davranışlarıyla bankaları doğrudan doğruya etkileyen beş çeşit hedef kitle bulunmaktadır (Yavuz, 1972, s.52). Bunlar; (1) banka müdüründen odaclya ve hizmet personeline kadar geniş çerçevede değerlendirilebilecek banka çalışanları ya da memurlar, (2) bankadan hizmet alan müşteriler, (3) bankanın hizmet ettiği ve çoğu kez sosyal sorumluluk çalışmalarıyla destekte bulunması gereken toplum, (4) banka hissedarları, (5) çiftçiler, din adamları, öğretmenler ve meslek sahipleri gibi bazı fikir liderleri ile yarının büyükleri olacak çocuklardan oluşan halk olarak sıralanabilmektedir. Bu anlamda bankalar imajlarına yönelik çalışmalar yürütürken tüm hedef kitlelerinin beklentilerini dikkate almalarının önemli olduğu ifade edilebilir.

Hizmet sektöründe yer alan ve çok geniş bir hedef kitleye hitap etme zorunluluğu olan bankaların tercih edilmesinde pek çok faktör etkili olabilmektedir. Fakat bunlar arasında halkla ilişkiler alanı çerçevesinde değerlendirildiğinde kurumsal imaj, kurumsal kimlik, kurumsal sosyal sorumluluk ve kurumsal iletişim gibi uygulama alanlarından hizmet sektöründe yer alan diğer kurumlar gibi bankaların da yararlandığı, bu yolla 
müşterilerinde güvenilir, kaliteli, hızlı ve etkin hizmet sunan kurum algısını oluşturmak istedikleri görülmektedir.

\section{Banka Tercihinde Rolü Olan Kurumsal İmaj Bileşenleri}

İmaj ait olduğu nesnenin görünürlüğünü oluşturan, insan ve nesne çokluğunda ve karmaşasında nesneye ve insana bir netlik ve bilinirlik sağlayan ve izleyicisini, alıcısını, tüketicilerini zaman kaybetmeden kendisine davet eden bir kavramdır (Taburoğlu, 2013, s.63). İmaj kendi başına bir anlam ifade etmez. Ancak onu algılayabilecek bir hedef kitleyi bulduğunda bir anlam ifade edebilir (Yazıcı, 1997, s.19). Kurumsal imaj bir kurumun içinde yaşadığı çevre tarafından kabulü olarak da ifade edilmektedir (Thøger ve Askegaard, 2001, s.295). Ayrıca imaj kişiden kişiye farklılaşabilmektedir (İlgüner ve Asplund, 2011, s.265). Linkemer'e göre imaj; kişilerin gördüğü ve algıladığı bașka kişiler ve kurumlar hakkında sahip oldukları izlenimler olarak tanımlanabilmektedir (Linkemer, 1997, s.6). Peltekoğlu ise; kurumsal imajı tanımlarken kurumların farklı hedef kitleler üzerinde oluşturduğu bir resim olarak ifade etmektedir (Peltekoğlu, 2014, s.576). Bakan'a göre bir kurum birçok açıdan hem kendi iç hedef kitlesi hem de dış hedef kitlelerin zihinlerinde kuruma yönelik izlenimler oluşturabilmektedir. Kurumları algılayan kitlenin bakış açılarına ve algılama şekillerine göre farklılık gösterebilen bu imaj, kurumsal imaj olarak tanımlanmaktadır (Bakan, 2011, s.300). Kuruma yönelik izlenimin vurgulandığı bir başka tanımda da kurumsal imaj, bireyin ya da bir grubun bir kuruma yönelik bütüncül ve ayrıntılı izlenimi olarak değerlendirilmektedir (Hatch vee Schultz, 1997, s. 359).

Günümüzde kurumsal imaj kavramı rekabet başarısıyla doğrudan bağlantılı kritik kurumsal varlıklardan biri olarak değerlendirilmektedir (Gray ve Balmer, 1998, s. 695). Günümüzde bireyler gibi tüm kurumların en değerli varlıkları arasında kurumların hedef kitleleri nezdindeki imajları yer almaktadır. Kamu ve özel sektör kurum ve kuruluşları tüm hedef kitleleri tarafından olumlu algılanmak isterler ve bunun içinde çeşitli iletişim ve halkla ilişkiler yöntemlerine başvururlar. Bu çabalar neticesinde kurum toplum tarafından kabul görebilir ve toplum tarafından desteklenir. Böylece kurum varlığını devam ettirebilir. İmaj bu anlamda kurumların rakipleri arasından sıyrılarak ön plana çıkma ve rekabet ortamında bir var olma mücadelesi olarak ifade edilebilir.

Kurumun hedef kitlesi nezdindeki imajı kurum tarafından ortaya konan davranış, üretilen ürün ya da hizmet ve bu süreçte hedef kitlelerle kurulan aktif olarak gerçekleşen iletişim yoluyla oluşmaktadır (Güllüpunar ve Tekmen, 2018, s.89). Kurumsal imaj, hedef kitlenin bir organizasyon hakkında sahip olduğu anlık zihinsel resmidir. Öyle ki kurumun hedef kitlesinin kurum hakkındaki olumlu ya da olumsuz algıları kurumun ürün satışlarına ve karına olumlu ya da olumsuz yönde etki edebilmektedir (Gray ve Balmer, 1998, s.697). Kurumlar bu gerçekten hareketle olumlu imaj oluşturma ve bunu pekiştirmeye dönük çeșitli halkla ilişkiler uygulamalarından yararlanmalıdır. Hedef kitlelerin zihinlerinde kurumun imajını oluşturan çeşitli faktörler vardır. Bakan $(2005$, s.178) kurumsal imajı oluşturan bu faktörleri etki sırasına göre; kalite, sosyal sorumluluk, halkla ilişkiler, reklam, görsel kimlik ve sponsorluk şeklinde sıralamaktadır. Kurumlar açısından imajın belirleyici unsurları olarak fiziksel görüntünün (sembollerin), kurumsal iletişimin ve kurumsal davranışın önemli olduğu ifade edilmektedir (Peltekoğlu, 2014, s.572; Gotsi ve Wilson, 2001, s.29).

Kurumların paydaşlarının algıları da çeşitli olabilmektedir. Çünkü her paydaş unsur işletmenin farklı yönlerini önemsemektedir. Tüketiciler esas olarak kurumun ürün ve hizmetlerinin güvenirliğini, kalitesini ve fiyatlarını ve daha da önemlisi kurumun sosyal 
ve etik politikalarını ve faaliyetlerini dikkate almaktadır. Finansal kurumlar kurumun finansal yapısı ve performansıyla ilgilenmektedir. Kurum çalışanları ise çoğunlukla maaş, çalışma koşulları ve personel politikaları ile ilgilenmektedir. Bundan dolayı kurumlar her paydaş grupla iletişimini ayrı ayrı ve özel gerçekleştirmelidir (Gray ve Balmer, 1998, s. 698-699). Bu açıdan kurumsal imaj oluşturmada kurumun ortaya koyacağı iletişim faaliyetlerinin önemli olduğu özellikle ifade edilmelidir.

Kurumsal imaj kurumun çalışanları ve dış hedef kitlesi arasındaki günlük etkileşimlerinden etkilenen bir kavramdır. Bu etkileşim bazen bir doktorun hastaya davranış biçimi iken, bazen de satış personelinin müşterilere yönelik yardımları ve bir danışma görevlisinin bir müşteriye verdiği tavsiyeleri olabilmektedir (Hatch ve Schultz, 1997, s.359).

Chun ve diğerleri (2004, s.125-146) ise imajın çok boyutluluğuna dikkat çekmekte ve imajın bu boyutlarını ise liyakat, uygunluk, girişkenlik, şık ve acımasızlık olarak ifade etmektedir. Liyakat boyutu kurumun güvenilirliği ve verimlilik oranını oluştururken; güven ve sosyal sorumluluk içeren faaliyetler ise uygunluk boyutunun bileșenleri olarak tanımlanmaktadır. Şıklık boyutu ise kurumun kültürlülük oranını yansıtırken, girişkenlik boyutunun ise heyecan ve yenilikçilik kavramlarına karşılık gelebileceği değerlendirilmektedir. Bu anlamda düşünüldüğünde kurumun girişken olması yeniliğe ve teknolojik gelişmelere açlk faaliyet ve hizmetlerle hedef kitlesine sunduğu olanaklar olarak değerlendirilebilir. Kurumun hedef kitle nezdinde uygun bir imaja sahip olması ise kurumun içinde yaşadığı toplumun ihtiyaçlarına yönelik ürettiği her türlü sosyal sorumluluk içeren ve güven veren davranışları olarak ifade edilebilir. Kurumların hedef kitlesinde uyandırdığı güvenilir kurum algısı da kurum hakkında liyakatli bir kurum imajının oluşmasına sebep olabileceği değerlendirilebilir.

Ticari bankaların kurumsal imajının bankaların sundukları hizmet boyutlarıyla, erişilebilirlikleriyle, sosyal sorumluluklarıyla, global izlenimleriyle, bankanın yaşam ve çalışma alanlarına konumu ve şube sayılarıyla ve personeliyle ilişkili olduğu değerlendirilmektedir (Bravo, Montaner ve Pina, 2009, s.315). Ayrıca teknolojik, sosyal ve kurumsal boyutlardan oluşan sürdürülebilir bankacılık yaklaşımı kurumsal imaja etki etmekte ve kurumsal imajın da bankalara yönelik müşteri sadakatini pekiştirmektedir (Igbudu, Garanti ve Popoola, 2018, s.7). Öyle ki bir müșterinin bir bankada hesap açması veya mali konuları görüşmesi ile bankaya olan güvenini gösterir ve böylece bankacılık hizmetleri başlar. Bankanın bundan sonraki hizmetleri, bankaya olan bu güven duygusunu devam ettirmek ve ona layık olma yolunda geliștirmektir. (Yavuz, 1972, s.158). Banka müşterilerine sunacağı ürün ve hizmetlerle güvenilir kurum olma algısını geliştirmeyi ve pekiştirmeyi hedeflemelidir. Buradan hareketle kurumsal imaj hedef kitlelerin bir kurum hakkında sahip oldukları bilgilere ve kurumun elde ettiği ve işlediği niteliklerine dayalı olarak oluşan tüm algıları olarak ifade edilebilir (Horng ve diğerleri, 2018, s.1009).

\subsection{Kurumsal Kimlik}

Literatürde kurumsal kimlik ve kurumsal imaj kavramlarının birbirilerinden farklılaşmakla birlikte birbirinin yerine kullanılabildiği ifade edilmiştir (Abratt, 1989, s.66). Bu anlamda Margulies (1997, s.66) kimlik kavramını bir kurumun müşteriler, çalışanlar, basın, mevcut ve potansiyel hissedarlar, yatırım bankacıları gibi tüm kamusuna kendisini tanıtmak için tercih ettiği tüm yöntemlerin toplamı olarak, imaj kavramını ise bu kamular tarafından kurumun algılanışı olarak ifade etmektedir. Balmer (2008, s.882) kurumsal kimlik kavramını tartıştığı çalışmasında, kimlik olmadan nasıl cinsiyet, karakter, din, millet gibi unsurlar hakkında bilgi sahibi olunamayacağı gibi bir kimlik olmadan 
kurumların anlaşılmasının imkansız olmasa da zorlaşacağını ifade etmektedir. Ayrıca kimliklerin karmaşık, çok boyutlu ve karakter olarak değişken olabileceğini ifade etmekte, bununla birlikte kimliklerin güçlerinin nasıl olduğu her zaman tam olarak anlaşılıp görülememesine rağmen, onların önemi reddedilemez olarak değerlendirmektedir.

Uluslararası Kurumsal Kimlik Birliği'nin kurumsal kimlik tanımında; her kurumun bir kimliğinin olduğu ifade edilmektedir. Kurumsal kimlik kurumsal ahlakı, amaçları, değerleri dile getirir ve rekabetçi piyasa koşullarında kurumu diğerlerinden ayrıştırıcı bir bireysellik sunar. Ayrıca kurumsal kimlik tüm kurumsal iletişimlerin birbiriyle uyum içinde olmasını temin etmek için görsel bir uyum sağlar ve kurumun ahlak ve karakteriyle tutarlı bir imajın oluşmasına da sebep olur. Etkili bir şekilde yönetilen kurumsal kimlikle, kurum çeşitli paydaşları arasında bir anlayış ve bağlılık inşa edebilir. Böylece kurum müşterilerini ve çalışanlarını etkileyebilir ve elinde tutabilir. Ayrıca stratejik ittifaklar sağlar, finansal piyasaların desteğini kazanır ve kuruma bir yön ve amaç duygusu kazandırır. Kurumsal kimlik stratejik bir konudur. Çünkü geleneksel marka pazarlamasından farklılaşarak kurumun tüm paydaşlarıyla ilgilenir (Balmer, 1998, s.985).

Kurumsal kimlik tözsel özelliklere sahip olan ve etkileri gözlemlenebilen bir yapıya sahiptir. Kurumsal kimliğin kendi kendine karar verici bir kapasiteye sahip olup, yönetilmeye ve kalıplandırılmaya elverişlidir. Kurumsal kimlikler aynı bireylerde olduğu gibi yasal olarak ayrı bir aidiyete sahiptir. Kurumsal kimlik kurumsal iletişim politikalarının geliştirildiği, kurumsal itibarın oluşturulduğu, kurumsal imajın oluşturulduğu merkezi bir platform sağlar (Balmer, 2008, s.886).

"Kurumsal kimlik", yeni bir logo tasarımı, iç dekorasyon, satış gücü eğitimi, kurum kültürünü değiştirmeye kadar çeşitli faaliyetler için bir gerekçe görevi gören genel amaçlı bir kavram gibi görünmektedir. Çoğu yazar kurumsal kimliği açıkça tanımlamaz. Tanımlarda ortak olan tek unsur "kurumsal kimliğin" "organizasyonu bir bütün olarak sembolize eden bir şey” anlamına gelmesidir (Van Rekom, 2007, s.410).

Bakan (2005, s.88) kuruluşların amaçladıkları ve oluşturmak istedikleri imaj için, kuruma ait olan mekânsal ve insana dair fiziksel çevrenin yapılandırılmasının önemini vurgulamaktadır. Kurumsal kimliğin mimari boyutuna işaret eden Yavuz da (1972, s.161162) banka binalarının (aydınlatma, iklimlendirme, tefrişat vb.) daha konforlu bileşenlere sahip olmasının müşteri ve bankalarda hizmet sunan banka çalışanlarının davranış biçimlerine olumlu yönde etki ettiğine dikkat çekmektedir. Genellikle trafiğin oldukça yoğun olduğu alanlarda hizmet sunan bankaların müşterilerine otopark olanakları sunması da artı bir zorunluktur. Böylece uygun fiziksel şartlara sahip banka binalarının hizmet veren ve alan kitle arasındaki iletişime olumlu yansıyacağı ifade edilmektedir (Yavuz, 1972, s.171-172).

Kurumsal imajı yönetenler açısından en önemli işlerden birisi, güçlü ve uzun dönemli bir kurumsal kimlik oluşturmaktır (Bakan, 2005, s.60). Kurumsal kimliğin kavramsal tanımı, kamuoyu nezdinde olumlu bir kurumsal imaja sahip olmak için bir kurumun stratejik olarak planlanmış ve amaçlı bir sunumudur. Kurumsal kimlik zaman içinde olumlu bir kurumsal itibar kazanmak için oluşturulur. Kurumsal kimliğin işlevsel tanımı ise; bir kurum kimliğinin ismi, logosu, marka sloganı, renk paleti ve mimarisi gibi gözlemlenebilir ve ölçülebilir unsurlarının tümünü içeren ancak bunlarla sınırlı olmayan kapsamlı görsel sunumunda kendini gösterir. Kurumsal kimlik ayrıca çalışanların, müşterilerin, hissedarların ve tedarikçilerin karşılanmasını içeren kurumun kamuya yönelik davranışlarını da içermektedir (Alessandri, 2001, s.177-178). Alessandri 
ayrıca çalışmasında; kurumsal kimliğin kavramsal ve işlevsel tanımlarına dayalı olarak kurumsal kimliğin nasıl çalıştığını gösteren bir model sunmaktadır. Bu model kurumsal kimliğin kurumsal felsefe, kurumsal imaj ve kurumsal itibarla olan ilişkisini göstermektedir (Şekil-1).

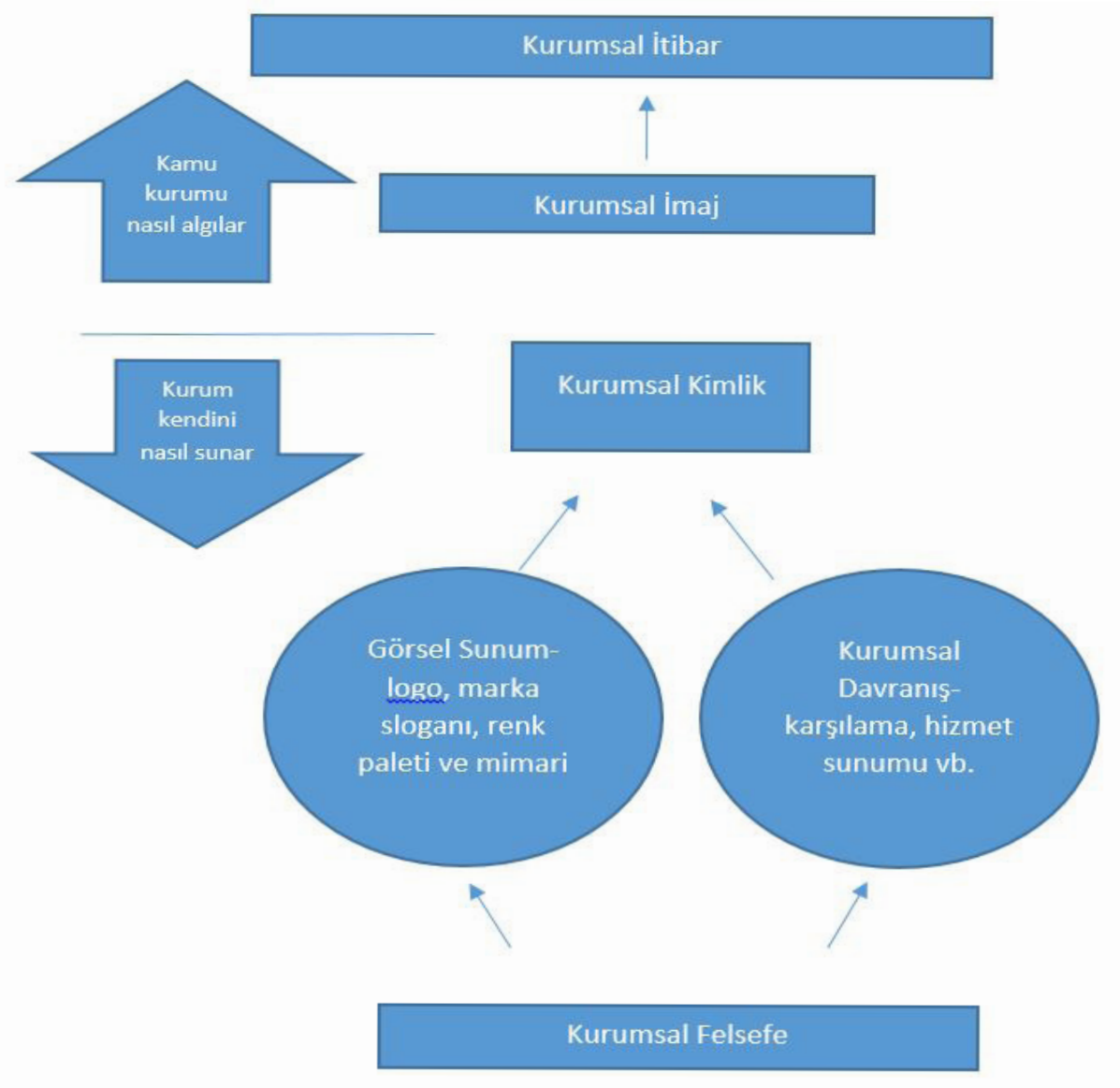

Şekil 1: Kurumsal Kimliğin İşleyiş Modeli

Alessandri'nin ortaya koyduğu tanımı esas alarak kurumsal kimliğin oluşumunda sadece görsel unsurların değil davranışsal unsurların da kurumsal kimlikle ilişkili olduğu söylenebilir. Bu açıdan kurumların hedef kitlelerine yönelik davranış biçimleri de kurumların kimliğiyle ilişkilidir. Böyle bir durumda kurumların bir diğer görsel yanının da kurumların davranışları olduğu da ifade edilebilir.

Kurumsal kimlik literatüründe kurumsal kimliğin yapısının üç ekole göre açıklamasının mevcut olduğu değerlendirilmektedir. Bu üç ekol görsel ekol, stratejik ekol ve yapısal ekol olarak sıralanmaktadır. Görsel ekol düşüncesi, kurumsal kimliği bir kurumu diğerlerinden ayrıştırıcı grafiksel unsurları (logo, marka vb.) olarak görmektedir. Bu tanım genellikle reklam ve iletişim ajanslarınca kullanılmaktadır. Stratejik ekol düşüncesi kurumsal kimliği bir kurumun misyon, vizyon ve felsefesinin bir karması olarak görmektedir. Yapısal ekole göre kurumsal kimlik kurumun iş ve ürünlerinin hatlarını nasıl yapılandırdığı (bir şirket isminin ayrıca marka ismi olması gibi) olarak ifade edilmektedir (Cian ve Cervai, 2014, s.188). Kurumsal kimliğin anlamı zaman içinde genişlemektedir. Kurumsal kimlik bir kurumun görünümünün dışarıya dönük sunumu olmakla birlikte, kurumun özgünlügü, tutarlılı̆̆ ve uyumluluğunu ifade eden içsel özellikleridir (Larcon ve Reitter'den aktaran; Balmer, 1998, s.977). 
Kurumsal kimlik kavramı, görsel kimlik alanı kapsamında yer alan temaların tamamını içermekle birlikte, kurumdaki çalışanların davranışları, kurum idarecilerinin yönetim biçimleri, işletme, üretim, hizmet anlayışı ve yöneticilerin kalitesi gibi faktörleri de içermektedir (Bakan, 2005, s.62). Ayrıca, kurum imajının oluşumunda etkili olan unsurlardan birisi olarak kurum kimliğinin yapısal bileşenleri arasında ifade edilen kurumsal davranış, kurumdaki tüm personelin hem kendi aralarında hem de diş hedef kitlelerle iletişim halindeyken ortaya koydukları davranış kalıpları olarak ifade edilebilmektedir (Elden, 2005, s.53). Bir diğer ifadeyle kurumsal davranış, bir kurumdaki bireylerin, birimlerin ya da grupların tutum ve davranışları olarak özetlenebilir (Doherty, 1998, s.1). Kurumsal kimlik kurumun çalışanlarının davranışlarını şekillendirir. Kurum kimliğiyle özdeşim sağlayan kurum çalışanları kurumun değerlerini kabul eder, bu değerlere göre davranışlarını ayarlar ve bunu hedef kitlelere iletirler (Brexendorf ve Kernstock, 2007, s.37). Müşterinin bankayı tanıması için başlıca yol banka personeli ile her günkü karşılaşmalarında edindiği intibalardır. Bir banka personelinin hizmet sunarken takındığı tavırların müşteriler üzerinde doğrudan doğruya tesiri olduğu unutulmamalıdır (Yavuz, 1972, s.54). Hizmet sektöründe yer alan bankaların çeşitli halkla ilişkiler enstrümanlarıyla personellerine gerekli eğitimleri sağlamaları ve müșterilere yönelik davranış biçimleri ile ilgili temel ilkeler belirlenmelidir.

\subsection{Sosyal Sorumluluk}

Kurumsal imaj oluşumunda, kurumların görünümü, iletişim yönetimi, tutum ve davranışları, kimliği gibi çeşitli bileşenler belirleyici olabilmektedir. Kurumsal sosyal sorumluluk faaliyetleri ve kurum felsefesi kurumsal tutum ve davranışlarda kendini göstermektedir. Böylece kurumsal sosyal sorumluluğun, kurumsal imajla ilişkili olduğu değerlendirilebilmektedir (Doğan ve Varinli, 2010, s.2). Toplumun genel iyiliğine yönelik olarak ortaya konan kurumsal sosyal sorumluluk faaliyetleri günümüz iş dünyasında daima trend bir değerdir. Toplumsal iyilikten anlașılması gereken, bir kurumun bir uygulamayı gerçekleştirirken ya da katkı sunarken faaliyetlerin arka planındaki gönüllülüktür (Pira, 2005, s.155).

Kurumların varlıklarını uzun sürede devam ettirebilmelerinde ortaya koydukları sosyal sorumluluk faaliyetlerinin önemli bir yeri vardır. Sosyal sorumluluk faaliyetleri kurumlar açısından müşterilerinin, ortaklarının, çalışanlarının, tedarikçilerinin ve kamuoyunun memnuniyetini ve güvenini kazanmasında ve devam ettirmesinde gerekli şartlardan birisi olarak ifade edilmektedir (Çerik ve Özarslan, 2008, s.588). Tüketiciler nezdinde ön planda olan bankalar kurumsal sosyal sorumluluk faaliyetleri ile kurumsal imajlarını geliştirmek istemektedir ( Castelo ve Lima, 2006, s.232).

Sosyal sorumluluk kavramının açıklamasında genellikle temel alınan Carrol'un (1979, s.500) çalışmasında sosyal sorumluluk kurumlarla ilişki içerisinde bulunan tüm hedef kitlelerin kurumlardan bekledikleri ekonomik, yasal, etik ve hayırseverlik faaliyetlerini içine alan bir kavram olarak tanımlanmaktadır. Kurumsal sosyal sorumluluk, kurumların faaliyetlerinin etki edebileceği çalışanlarla ilgili konular, toplumsal katılım, çevre sorunları ve diğer etik konular gibi birçok alanla ilgili olabilmektedir (Castelo ve Lima, 2006, s.245). Sosyal sorumluluk eğitim, sanat, spor, sağlık, çevre sorunlarına yönelik duyarlı her türlü etkinliği kapsayan toplum yararını önceleyen faaliyetler olarak ifade edilmektedir (Çoban ve İrmiş, 2018, s.68).

Günümüzde kurumların başarılı olup olmadığı sadece ticari ölçütlerle değil, içinde yaşadıkları çevreye hangi düzeyde katkı sağladıklarının karşılığı olan sosyal 
sorumluluklarıyla da ölçülmektedir. Kurumların ortaya koydukları sosyal sorumlulukları iş stratejilerinin bir parçası halini almıştır. Kurumlar sosyal sorumluluklarının farkında olup, geleceği görebilme ve sorumluluklarının devamlılığını sağlayabilme noktasında bir vizyona sahip oldukları sürece varlıklarını devam ettirebilecek ve rakiplerine karşı güçlü olabileceklerdir (Solmaz, 2005, s.117).

Kurumlar karlılıklarını kalıcı hale getirmek ve toplum nezdinde meşrulaşmış bir marka olarak anılabilmek için hizmet verdikleri topluma karşı duyarlı davranışlar olarak ifade edilebilecek sosyal sorumluluk faaliyetlerine önem vermektedir (Güllüpunar, 2010, s.33). Kurumların sosyal sorumluluk faaliyetleri hem toplumsal hem de evrensel sorunlara yönelik önemli çözüm stratejileri arasında ifade edilmektedir. Kurumların toplumsal ve kurumsal devamlılıkları toplumun çözüm gerektiren ihtiyaçlarına yönelik duyarlı olmasıyla ilişkilidir. Bu nedenle kurumlar toplumsal sorunların çözümünde aktif rol almayı da kurumsal anlamda bir sorumluluk olarak üstelenmektedir (Peltekoğlu ve Tozlu, 2018, s.287). Kurumlar toplum nezdinde olumlu bir algı oluşturmak, hedef kitlenin kuruma, kurumun markalarına, ürünlerine ve hizmetlerine yönelik tutumlarını olumlu anlamda etkilemek için sosyal sorumluluk projeleri üretmektedirler (Aslan ve Aydın, 2018, s.146).

Sosyal sorumluluk faaliyetinde bulunan kurumlar eğitime, sanata, kültüre, sosyal meselelere, çevre ile ilişkili sorunlara yönelik ortaya koydukları projelerle devletin bu alanlardaki yüküne ortak olmaktadır. Böylece toplumun gelişmişlik düzeyine, bireylerin bilinçlenmesine, toplumsal bütünleşmeye, toplumun ekonomisine katkl sağlayarak toplum nezdine takdirle karşılanarak kurumsal devamlılıklarında ciddi bir kazanç ve destek görmüş olacaktır (Çoban ve İrmiş, 2018, s.76). Bu anlamda yatırım kararları verilirken de kurumların sosyal sorumluluğun iki bileşeninden olan çevresel ve sosyal konulardaki performansına yönelik durumları oldukça önemli görülmektedir (Dyck ve diğerleri, 2019, s.693). Paydaşların kurumdan beklentilerine yönelik olarak ortaya konulan sosyal sorumluluk faaliyetleri kurumların uzun dönemde itibar kazanmasına ve ticari performansını artırmasına katkı sağlar (Karabey ve Battal, 2018, s.2250).

Bankalar daha iyi hayat şartlarına olanak sağlayacak toplum faaliyetlerine lider veya aktif iştirakçiler olarak katılırlar. Böylece, bankalar sosyal sorumluluğun öneminin farkına vardıklarını ortaya koymakta, müșteri kazanmak kadar dost kazanmanın öneminin de kavrandığını ifade etmiş olurlar. Bankacılar kazançlarının bankacılık işleri kadar, toplum faaliyetleri için de harcayarak (Yavuz, 1972, s.196) sadece kar elde etmeyi düşünmediklerini aynı zamanda topluma artı değer kazandırmanın da bilincinde oldukları yönünde kamuoyuna net mesajlar verme fırsatını yakalarlar.

\subsection{Kurumsal İletişim}

İletişim toplumsal ya da bireylerarası yaşam ile sınırlanmaması, bütüncül bir şekilde ele alınarak tüm yaşamın, yaşam alanlarının ve yaşam pratiklerinin vazgeçilmez bir unsuru olarak düşünülmesi gereken toplumsal gerçekliğin sürekli üretildiği ve düzenlendiği bir süreçtir (Çamdereli, 2015, s.14-15). Sosyal bir varlık olan insanın yaşamını devam ettirebilmesi için gereksinim duyulan en temel beceri iletişimdir. İnsanlar tarafından oluşturulan tüm kurumsal yapılarda da, iletişim bir harç ve çimento görevi üstlenir ve adeta kurumların yapı taşıdır (Taşcı ve Eroğlu, 2008, s.29). Bu bağlamda düşünüldügünde günümüz kurumlar dünyasında iletişim kurumların inşasının temelinde ve yaşam evrelerinin merkezinde yer aldığı ifade edilebilir. İletişim önce kurumun kendisini anlamasına ve anlamlandırmasına sonrasında da nasıl algılanmak istediği kaygısına 
hizmet eder. Böylece gerçekleştirilecek iletişim faaliyetleri ile kurumun imajı da şekillendirilmiş olacaktır.

Öz bir tanımla, halkla ilişkilerin temel konularından birisi olarak kurumsal iletişim (Bilbil, 2012, s.68); kurumsal hedeflere ulaşabilmek için kurumların gerçekleştirmesi zorunlu olan genel iletişim çalışmaları olarak tanımlanmaktadır (Tosun, 2003: 174). Solmaz'ın (2004, s.123) tanımında ise kurumsal iletişim; kurumun amaçlarına ulaşması ve kurumsal işleyiş için gerekli olan üretim ve yönetim sürecinde, kurumu meydana getiren tüm öğeler arasındaki uyumu, bilgi akışını, motivasyonu, bütünleşmeyi, değerlendirmeyi, eğitim, karar alma ve denetimi sağlamak amacıyla belirli kurallar kapsamında ortaya çlkan iletişim sürecidir.

Kurumlar iletişimin olanaklarını verimli kullanamadan paydaşlarına ulaşamaz. Böyle bir durumda kurum kendini anlatamaz. Kurumun anlaşılır olması paydaşları tarafından kurumun tanınırlığını, kabul edilebilirliğini ve tercih edilebilirliğini etkiler. Bunun yolu da kurumsal iletişim çalışmalarına dikkat eden ve sürekli iletişime açı olan bir kurum olmaktan geçer. Paydaşlarını dinleyen ve onların ne dediklerini anlama çabasında olup bu çabanın karşılığında dönütler üretebilen kurumların kurumsal iletişimi dikkate aldığı ifade edilebilir. Kuruluş iletişim kurarken iç paydaşlarına ve dış paydaşlarını etkili iletişim kanalları ile ulaşabildiği oranda bu sürekliliği devam ettirebilir.

İç ve dış paydaşlar olarak ifade edilebilen paydaş kavramı kapsamında iç paydaşlar kurumun çalışanları ve üst yöneticileri olarak tanımlanabilmekte iken, dış paydaşlar ise medya, STK, kamusal kurumlar, müşteriler ve rakipleri işaret ettiği değerlendirilmektedir. İşte bu noktada, kurumlar için çeşitli dış paydaşlara katılımda bulunmak için elektronik medya (televizyon ve radyo), yazılı medya (gazete ve dergi) ve yeni medya (internet) gibi kitle iletişim araçları paydaşları ikna etmek için kullanılan en etkili araçlar arasında sıralanabilmektedir (Mohamad ve diğerleri, 2019, s.73). Günümüzde de birçok kurum gelişen iletişim teknolojilerinin birçok olanağını kurumun menfaatleri ve kurumsal işleyişine uygun şekilde kurumsal iletişim açısından dönüştürerek kullanmaktadır. Çünkü teknolojik olarak etkinleștirilmiş iletişim, şirketlerin ses ve görüntüyle doğrudan ilgili olmalarına ve şirketlerin esas müşterilerine bunu yansıtmalarına olanak sunar. Örneğin, bir kurumun web sayfasının giriş görünümü, uyandırdığı his, sitedeki farklı bilgilere ulaşımın kolaylığı kurum hakkında olumlu ya da olumsuz izlenimleri ve kurumun en çok önemsediği değerlerin neler olduğunu hedef kitlere aktarabilir. Teknolojinin kurumsal iletişim üzerindeki etkisinin farkında olmak demek, teknoloji kullanımında en yenilikçi yollara öncülük eden pratiklere sahip olmak demektir (Foreman ve Argenti, 2005, s.260). Bankacılık ve finans sektörü teknolojinin yardımıyla hizmet sunumunu çeşitlendiren hizmet sektörlerinin başında gelmektedir. İnternetin yaygınlaşmasıyla birlikte neredeyse tüm bankalar, internet bankacılığı hizmetlerini yaygınlaştırmakta ve bu hizmetten yararlanan müşteri sayısını artırmada teşvik edici bir rol oynamaktadırlar (Sayımer, 2008, s.196). Hatta günümüzde yine internet tabanlı mobil bankacılık hizmetleri de giderek bankaların hizmet sunumlarında yeni bir mecra olarak dikkat çekmektedir. Özellikle cep telefonu kullanıcı sayısının her geçen gün arttı̆̆ı ülkemizde bankaların bu yeni hizmet sunum biçiminden yararlanmaları da daha hızlı hizmet sunma biçimlerini geliştirmede önemli katkılar sunmaktadır. Kurumsal iletişim kurumların tüm paydaşlarına nezdinde şeffaf görünmesi temeline dayandığı şeklinde ifade edilebilir (Christensen, 2002, s.162). 


\section{Yöntem}

Bankalardan hizmet alan bireylerin ilgili banka/ları tercihlerinde halkla ilişkilerin hangi unsurlarının rolü olduğunu belirlenmeye yönelik bir alan araştırması gerçekleştirilmiştir. $\mathrm{Bu}$ araștırmada güvenlik, kurumsal davranış, kurumsal iletişim, kurumsal görünüm ve kurumsal sosyal sorumluluk unsurlarının hangi düzeyde rolünün olduğu sorgulanmıştır. Alanda bu konuyla ilgili yerli ve yabancı literatürde doğrudan bir çalışma olmadığından anket formu Bakan'ın (2005) ve Gürbüz'ün (2017)'ün ilgili çalışmalarından yola çıkarak araștırmacılar tarafından oluşturulmuştur. Kurumsal İmaj Bileşenleri Ölçeği olarak adlandırılan anket sahaya uygulanmadan önce halkla ilişkiler alanında uzman iki araștırmacının görüşü alınmıștır. Ayrıca anket formu 50 kişiye ön test yapılarak pilot bir araştırma sürecinden geçirilmiş ve son şekli verilmiştir. Anket formu toplam 45 sorudan oluşmaktadır. Anket formunu oluşturan ilk 35 soruda 5'li Likert tipi (kesinlikle katılmıyorum $=1$, katılmıyorum $=2$, fikrim yok=3, katılıyorum $=4$, kesinlikle katılıyorum=5) ölçek kullanılmıștır. Ölçekle katılımcıların banka tercihlerinde rolü olan kurumsal imaj bileşenleri belirlenmeye çalışılmıştır. Bunların yanında 5 soru katılımcıların sosyodemografik özelliklerini belirlemeye yönelik iken, kalan 5 soru ise ankete katılanların banka hizmetlerinden yararlanma pratiklerini ortaya koymayı amaçlamıştır.

Bankaların tercihinde rolü olan kurumsal imaj bileșenlerini belirlemeye yönelik gerçekleştirilen alan araștırmasının evrenini Konya'da ikamet eden 18 yaş ve üzeri tüm bireyler oluşturmaktadır. Ankette katılımcılar tesadüfi örneklem tekniği kullanılarak belirlenmiştir. Anket uygulaması Nisan-Haziran 2019 tarihleri arasında gerçekleştirilmiştir. Araştırmanın gerçekleștirildiği Konya Kent nüfusu 2018 yılı TÜİK verilerine göre 2.205.609'dur (Türkiye İstatistik Kurumu, 2018). Balcı'ya göre (2004:95) \%5 hata payında 25.000.000 kişiden oluşan evrenin örneklemi 384 olarak ifade edilmektedir. $\mathrm{Bu}$ veriden hareketle toplam 600 anketin uygulanması kararlaștırılmış ancak anketlerden 42 tanesi çeşitli nedenlerle tamamlanamadığı için analiz dişı tutulmuş ve toplamda 558 anket üzerinde değerlendirmeler yapılmıştır. Buna göre araștırma yapılan örneklemin evreni temsil eder nicelikte olduğu söylenebilir.

Banka tercihinde etkisi olan faktörleri belirlemeye yönelik olușturulan araștırma hipotezleri aşağıda sunulmaktadır:

1. Bireylerin banka tercihine en çok rolü olan değişken kurumsal iletişimdir.

2. Yaş arttıkça banka tercihinde güvenlik değişkenine verilen önem artmaktadır.

3. Eğitim düzeyi arttıkça banka tercihinde etkili olan sosyal sorumluluk faaliyetlerine verilen önem artmaktadır.

4. Kredi kartı sahip olan bireyler, banka tercihinde güvenlik değişkenine daha fazla önem vermektedir.

5. Yeni iletişim teknolojileri üzerinden bankacılık hizmeti alanlar güvenlik değişkenine daha fazla önem vermektedir.

Ayrıca çalışmanın çıkış noktası olarak kurgulanan araştırma soruları ise şu şekildedir:

1. Banka tercihinde en çok rolü olan kurumsal imaj değișkeni nedir?

2. Banka tercihinde rolü olan kurumsal imaj değişkenleri arasında ne tür bir ilişki vardır?

3. Banka tercihinde rolü olan maddelerin önem düzeyleri nasıldır? 
4. Banka tercihinde halkla ilişkiler çalışmalarının rolü ve önemi nedir?

5. Katılımcıların bankalardan hizmet alma biçimleri nelerdir?

Değerlendirmeler, elektronik ortama aktarılan veriler aracılığıyla araştırmanın amacına uygun olarak analizler yapılmıștır. Verilerin analizinde katılımcıların demografik özellikleri, bankalardan hizmet alma düzeyi ve biçimlerinin tespitinde frekans analizi; banka tercihlerinde rolü olan kurumsal imaj bileșenleri önem düzeylerinin belirlenmesinde aritmetik ortalama, katılımcıların sosyo-demografik özellikleri ve bankadan hizmet alma biçimleri ile banka tercihinde etkili olan değişkenler arasındaki ilişkilerin belirlenmesinde t testi, ANOVA ve korelasyon analizlerinden yararlanılmıștır.

\section{Bulgular}

\subsection{Katılımcıların Sosyo-demografik Özellikleri ve Bankalardan Hizmet Alma Pratikleri}

Araştırmaya katılanların 251'i (\%45) erkek, 307'si (\%55) ise kadınlardan oluşmaktadır. Bu sonuçlara göre katılımcıların cinsiyete göre dengeli bir dağılımından söz edilebilir.

Araștırmaya katılanların yaşlarına göre dağılımlarına bakıldığında 284'ü (\% 50.9) 18-25 yaş; 98'i (\%17.6) 29-38 yaş; 98'i (\%17.6) 39-48 yaş; 43’ü (\%7.7) 49-58 yaş; 35’i (\%6.3) 59 yaş ve üzeri katılımcılardan oluşmaktadır. Katılımcıların büyük çoğunluğunun \% 86.1 ile genç ve orta yaş grubundaki katılımcılardan oluştuğu söylenebilir.

Katılımcıların eğitim durumuna göre dağılımlarına bakıldığında 50'sinin (\%9.0) ilkokul; 61'inin (\%10.9) ortaokul; 108'inin (\%19.4) lise ve 339'unun (\%60.8) üniversite düzeyinde eğitime sahip olduğu değerlendirilmiștir.

Katılımcıların aylık ortalama harcama miktarı da yanıt aranan bir başka sorudur. Buna göre 332'sinin (59.5) 2020 TL ve altı, 162'sinin (\%29) 2021-4000 TL; 42'sinin(\%7.5) 4001-6000 TL ve 22'sinin (\%3.9) 6001 TL ve üzeri aylık ortalama harcama yaptıkları bulgulanmıştır.

Katılımcıların mesleki durumları değerlendirildiğinde 249'unun (\%44.6) öğrenci; 96'sının (\%17.2) işçi; 48'inin (\%8.6) memur; 48'inin (\%8.6) ev hanımı; 34'ünün (\%6.1) serbest meslek; 34'ünün (\%6.1) emekli; 22'sinin (\%3.9) esnaf; 13'ünün (\%2.3) öğretmen; 12 'sinin (\%2.2) sanayici-tüccar ve 2'sinin (\%0.4) ișsiz olduğu görülmektedir.

\subsection{Katılımcıların Bankalardan Hizmet Alma Pratikleri}

Katılımcılara kredi kartlarının olup olmadıklarına ilişkin yöneltilen soruya katılımcıların 367'si (\% 65.8) kredi kartlarının olduğunu, 191'i (\% 34.2) ise kredi kartına sahip olmadıklarını belirtmiștir.

Kredi kartı olan katılımcılara kaç tane kredi kartına sahip olduklarına ilişkin sorulan soruya 193'ü (\% 34.6) bir, 109’u (\% 19.5) iki, 50’si (\% 9.0) üç, 11'i (\% 2.0) dört ve 3'ü ise (\% 0.5) beş tane kredi kartına sahip olduklarını belirtmişlerdir.

Katılımcılara kaç bankada hesaplarının olduğu sorulmuş ve 37'si (\% 6.0) hiçbir bankada hesaplarının olmadığını belirtmiștir. Bununla birlikte 228 kiși (\% 40.9) bir, 157 kiși (\% 28.1) iki, 87 kişi (\% 15.6) üç, 32 kişi (\% 5.7) dört ve 17 kişi ise (\% 3.0) beş bankada hesaplarının olduğunu ifade etmektedirler.

Katılımcılara hizmet aldıkları banka ile ilgili haberleri daha çok hangi kitle iletişim aracından aldıklarına ilişkin soruya 380'i (\% 68.1) internet, 96'sı (17.2) televizyon, 77’si (\% 13.8) sosyal medya, 3’ü (\% 0.5) gazete ve 2’si (0.4) ise dergi yanıtını vermiştir. 
Katılımcıların büyük çoğunluğunun hizmet aldıkları bankalarla ilgili olarak yeni iletişim teknolojilerini kullanarak bilgi edindikleri söylenebilir. Bu durum daha çok genç ve orta yaş katılımcıların ankete katılımlarıyla da örtüşmektedir.

Bankalardan hizmet alma biçimlerine ilişkin de bir soru yöneltilmiştir. Buna göre; 206'sı (\% 36.9) internet bankacılığı, 179'u (\% 32.1) ATM, 105'i (\% 18.8) mobil uygulamalar ve 68'i (\% 12.2) banka şubelerinden hizmet aldıklarını ifade etmiştir.

\subsection{Katılımcıların Banka Tercihlerine Etki Eden Unsurlar}

Katılımcıların banka tercihlerinde etkili olan unsurları belirlemeye yönelik 35 maddeden oluşan bir ölçek uygulanmıştır. Ölçeğin Cronbach's Alpha değeri .917 olarak yüksek bir değerle karşıllık bulmuştur. Bu bulgu ölçekte yer alan yargıların banka tercihlerini belirlemede kullanışlı olduğunu göstermesi bakımından değerlidir.

Tablo 1: Bankaların Imajına Ait Belirleyicilerin Merkezi Eğilim İstatistikleri

\begin{tabular}{|c|c|c|c|c|c|}
\hline & SAYI & $\begin{array}{c}\text { EN } \\
\text { DÜşÜK }\end{array}$ & $\begin{array}{c}\text { EN } \\
\text { YÜKSEK }\end{array}$ & ORTALAMA & SD \\
\hline Banka personeli güvenilir olmalıdır. & 558 & 1 & 5 & 4,8548 & ,47796 \\
\hline Banka ATMleri güvenli olmalıdır & 558 & 1 & 5 & 4,8548 & ,45879 \\
\hline Banka personeli müşterilere anlayışı davranmalıdır. & 558 & 1 & 5 & 4,8423 & ,46824 \\
\hline $\begin{array}{l}\text { Banka çalışanları müşterilerin } \\
\text { şikayetlerini dikkate almalıdır. }\end{array}$ & 558 & 1 & 5 & 4,8369 & ,47213 \\
\hline Banka çalışanları müşterilerle saygılı konuşmalıdır. & 558 & 1 & 5 & 4,8280 & ,47464 \\
\hline Banka binaları güvenli olmalıdır. & 558 & 1 & 5 & 4,8244 & ,59439 \\
\hline $\begin{array}{l}\text { Banka ile her türlü (yazılı, sözlü, telefonla) } \\
\text { iletişim kurmak kolay olmalıdır. }\end{array}$ & 558 & 1 & 5 & 4,8190 & ,46167 \\
\hline $\begin{array}{l}\text { Hizmet alan engelli vatandaşlara yönelik } \\
\text { kolaylaştırıcı tedbirler almalıdır. }\end{array}$ & 558 & 1 & 5 & 4,8118 & ,51064 \\
\hline $\begin{array}{l}\text { Banka çağrı merkezi personeli çözüm } \\
\text { üreten bir anlayışla hizmet sunmalıdır. }\end{array}$ & 558 & 1 & 5 & 4,8047 & ,49360 \\
\hline İnternet bankacılığı güvenilir olmalıdır. & 558 & 1 & 5 & 4,7975 & ,54281 \\
\hline Banka çağrı merkezlerine erişim hızlı olmalıdır & 558 & 1 & 5 & 4,7957 & ,48070 \\
\hline Mobil bankacılık hizmetleri güvenilir olmalıdır. & 558 & 1 & 5 & 4,7939 & ,55132 \\
\hline $\begin{array}{l}\text { Banka çalışanları hizmet sundukları } \\
\text { alanda uzman olmalıdır. }\end{array}$ & 558 & 1 & 5 & 4,7240 &, 58019 \\
\hline Mobil bankacılık sistemi kullanışı olmalıdır. & 558 & 1 & 5 & 4,7151 & ,59576 \\
\hline Bankanın internet bankacılığı kullanışı olmalıdır. & 558 & 1 & 5 & 4,7061 & ,61373 \\
\hline Bankaların bina içleri temiz ve düzenli görünmelidir. & 558 & 1 & 5 & 4,6667 & ,63698 \\
\hline $\begin{array}{l}\text { Çalışan personelin kıyafetleri (banko } \\
\text { görevlisi, güvenlik, temizlik işçileri vs.) } \\
\text { temiz ve düzenli görünmelidir. }\end{array}$ & 558 & 1 & 5 & 4,6452 & ,61364 \\
\hline Banka içi yönlendirme levhaları yeterli olmalıdır. & 558 & 1 & 5 & 4,6039 & ,66385 \\
\hline Bankaların aydınlatmaları yeterli olmalıdır. & 558 & 1 & 5 & 4,5125 & ,72826 \\
\hline Bankaların ısınma olanakları yeterli olmalıdır. & 558 & 1 & 5 & 4,4158 & ,76684 \\
\hline $\begin{array}{l}\text { Banka reklamları bankanın hizmetleri } \\
\text { hakkında bilgilendirici olmalıdır. }\end{array}$ & 558 & 1 & 5 & 4,4014 & ,89691 \\
\hline Şube önünde yeterli otoparkı olmalıdır. & 558 & 1 & 5 & 4,3781 & ,83807 \\
\hline Bankalar eğitime yönelik projeler üretmelidir. & 558 & 1 & 5 & 4,3692 & ,85790 \\
\hline İç dekorasyonu modern bir görünüşe sahip olmalıdır. & 558 & 1 & 5 & 4,3620 & ,87748 \\
\hline Bankalar sağlık alanındaki faaliyetleri desteklemelidir. & 558 & 1 & 5 & 4,3369 & ,88134 \\
\hline Çevre sorunlarına karşı duyarlı çalışmalar yapmalıdır. & 558 & 1 & 5 & 4,2867 & ,89093 \\
\hline
\end{tabular}




\begin{tabular}{|l|c|c|c|c|c|}
\hline & SAYI & $\begin{array}{c}\text { EN } \\
\text { DÜŞÜK }\end{array}$ & $\begin{array}{c}\text { EN } \\
\text { YÜKSEK }\end{array}$ & ORTALAMA & SD \\
\hline $\begin{array}{l}\text { Bankalar sosyal sorumluluk } \\
\text { projelerine katkı sağlamalıdır. }\end{array}$ & 558 & 1 & 5 & 4,2616 &, 88859 \\
\hline Banka logoları kurumu görsel olarak tanıtmalıdır. & 558 & 1 & 5 & 4,2509 &, 91160 \\
\hline $\begin{array}{l}\text { Bankalar sosyal medya hesapları üzerinden } \\
\text { müşterilerin sorularına yanıt vermelidir. }\end{array}$ & 558 & 1 & 5 & 4,2186 & 1,11407 \\
\hline Banka içi ücretsiz iletişim araçları olmalıdır. & 558 & 1 & 5 & 4,1953 &, 95285 \\
\hline ATMler modern bir görünüşe sahip olmalıdır. & 558 & 1 & 5 & 4,1918 & 1,05545 \\
\hline Banka medyada olumlu haberlerle yer bulmalııı. & 558 & 1 & 5 & 4,1416 & 1,04118 \\
\hline Bankalar kültür-sanat faaliyetlerini desteklemelidir. & 558 & 1 & 5 & 4,0789 &, 97411 \\
\hline $\begin{array}{l}\text { Bankaların çeşitli alanlarda sponsorluk } \\
\text { faaliyetleri olmalıdır. }\end{array}$ & 558 & 1 & 5 & 4,0448 &, 93973 \\
\hline Bankalar spor faaliyetlerini desteklemelidir. & 558 & 1 & 5 & 3,9875 & 1,03173 \\
\hline
\end{tabular}

Katılımcıların banka tercihlerinde en fazla etkili olan üç yargıya bakıldığında banka personeli güvenilir olmalıdır (A.0.= 4.85), banka ATMleri güvenli olmalıdır (A.0.= 4.85) ve banka personeli müşterilerine anlayışlı davranmalıdır (A.O.= 4.84) yargıları göze çarpmaktadır. Bununla birlikte en düşük önem atfedilen maddeler ise; bankalar kültürsanat faaliyetlerini desteklemelidir (A.0.= 4.07), bankalar çeşitli alanlarda sponsorluk faaliyetlerine destek olmalıdır (A.0. 4.04 ) ve bankalar spor faaliyetlerini desteklemelidir (A.0.= 3.98). bu bulgulara göre katılımcıların banka tercihlerinde kurum imajına yönelik belirleyiciler açısından en çok güvenlik değişkenine önem verdikleri ifade edilmelidir.

\subsection{Banka İmajını Oluşturan Değişkenlere Ait Betimleyici Bulgular}

Katılımcıların banka tercihlerine etki eden ve aynı zamanda banka imajını oluşturan yargıları belirlemek üzere beş temel değişken kompüt edilerek aritmetik ortalama değerleri analiz edilmiştir. Buna göre, banka imajına en çok etki eden değişken güvenliktir (A.0.= 4.82). Bunu kurumsal davranış (A.0.= 4.80), kurumsal iletişim (A.0.= 4.49), kurumsal görünüm (A.0.=4.48) ve kurumsal sosyal sorumluluk (A.0.=4.27) takip etmektedir.

Tablo 2: Banka İmajına Ait Değişkenlerin Merkezi Eğilim İstatistikleri

\begin{tabular}{|l|c|c|c|c|c|}
\hline \multicolumn{7}{|c|}{ Descriptive Statistics } \\
\hline & Sayı & Min. & Max. & Ort. & SD \\
\hline Güvenlik & 558 & 1,00 & 5,00 & 4,8253 &, 43384 \\
\hline Kurumsal Davranış & 558 & 1,00 & 5,00 & 4,8072 &, 41939 \\
\hline Kurumsal İletişim & 558 & 2,25 & 5,00 & 4,4991 &, 48072 \\
\hline Kurumsal Görünüm & 558 & 1,30 & 5,00 & 4,4851 &, 51833 \\
\hline Kurumsal Sosyal Sorumluluk & 558 & 1,75 & 5,00 & 4,2722 &, 61167 \\
\hline Valid N (listwise) & 558 & & & & \\
\hline
\end{tabular}

Banka tercihinde kurumsal iletişim uygulamalarının en çok etkisi olduğunu varsayan hipotez 1, bu sonuçlardan hareketle reddedilmiştir. Kurumsal iletişim banka tercihinde üçüncü sırada önem atfedilen bir değişken olarak belirlenmiştir. Özellikle katılımcıların ekonomik faaliyetlerini yürüttükleri kurumlar olan bankalarda güvenlik unsurunu birinci sırada değerlendirmeleri dikkat çeken bir bulgu olmuştur. Bunlar yanında hizmet sektöründe faaliyet gösteren bankaların ve banka çalışanlarının davranışlarının ise katılımcılar tarafından ikincil düzeyde önemli görülmesi de hizmet sektörünün yapısı gereği doğal bir sonuç olarak değerlendirilebilir. Burada dikkat çeken husus kurumsal sosyal sorumluluk değișkeninin önem düzeyi bakımından son sırada yer almasıdır. 


\subsection{Bankaların İmajında Rolü Olan Unsurlar ile Yaş Durumu}

Tablo 3: Banka İmajı Oluşumunda Rolü Olan Değişkenler İle Yaş Durumu

\begin{tabular}{|c|c|c|c|c|}
\hline FAKTÖRLER & YAŞ & ORTALAMA & F Testi & P Değer \\
\hline \multirow{5}{*}{ Güvenlik } & $18-28$ & 4.87 & \multirow{5}{*}{4.27} & \multirow{5}{*}{.002} \\
\hline & $29-38$ & 4.82 & & \\
\hline & $39-48$ & 4.81 & & \\
\hline & $49-58$ & 4.66 & & \\
\hline & 59 yaş ve üzeri & 4.62 & & \\
\hline \multirow{5}{*}{ Kurumsal Davranış } & $18-28$ & 4.79 & \multirow{5}{*}{1.90} & \multirow{5}{*}{.108} \\
\hline & $29-38$ & 4.84 & & \\
\hline & $39-48$ & 4.80 & & \\
\hline & $49-58$ & 4.68 & & \\
\hline & 59 yaş ve üzeri & 4.93 & & \\
\hline \multirow{5}{*}{ Kurumsal İletişim } & $18-28$ & 4.59 & \multirow{5}{*}{7.64} & \multirow{5}{*}{.000} \\
\hline & $29-38$ & 4.44 & & \\
\hline & $39-48$ & 4.42 & & \\
\hline & $49-58$ & 4.28 & & \\
\hline & 59 yaş ve üzeri & 4.32 & & \\
\hline \multirow{5}{*}{ Kurumsal Görünüm } & $18-28$ & 4.51 & \multirow{5}{*}{1.63} & \multirow{5}{*}{.165} \\
\hline & $29-38$ & 4.49 & & \\
\hline & $39-48$ & 4.44 & & \\
\hline & $49-58$ & 4.32 & & \\
\hline & 59 yaş ve üzeri & 4.54 & & \\
\hline \multirow{5}{*}{$\begin{array}{l}\text { Kurumsal } \\
\text { Sosyal Sorumluluk }\end{array}$} & $18-28$ & 4.39 & \multirow{5}{*}{6.96} & \multirow{5}{*}{.000} \\
\hline & $29-38$ & 4.17 & & \\
\hline & $39-48$ & 4.13 & & \\
\hline & $49-58$ & 4.02 & & \\
\hline & 59 yaş ve üzeri & 4.21 & & \\
\hline
\end{tabular}

Güvenlik, kurumsal davranış, Kurumsal İletişim, Kurumsal Görünüm ve Kurumsal Sosyal Sorumluluk faktörlerin /değișkenlerin araștırmaya katılanların yaşlarına göre farklılașıp farklılaşmadığını test etmek amacıyla tek yönlü varyans analizi (ANOVA) uygulanmıştır. Tablo 3'de ayrıntılı olarak sunulan sonuçlar incelendiğinde, güvenlik ( $\mathrm{F}=4.27 ; \mathrm{p}<$ .05 ); kurumsal iletişim ( $\mathrm{F}=7.64$; $\mathrm{p}<.05)$; kurumsal sosyal sorumluluk ( $\mathrm{F}=6.96$; $\mathrm{p}<$ .05) katılımcıların yaşına göre anlamlı bir şekilde farklılaşan değişkenler olarak tespit edilmiştir. Kurumsal davranış değişkeni $(F=1.90$; $p>.05)$ ve kurumsal görünüm $(F=1.63$; p>.05) ile katılımcıların yaşları arasında anlamlı bir ilişki tespit edilememiştir.

Hangi yaş grupları arasında farklılaşma olup olmadığını tespit etmek için Tukey testi yapılmıştır. Çoklu karşılaştırma tablosuna bakıldığında 18-28 yaş grubunda (A.0.= 4.87) yer alan bireylerin güvenlik değişkenine verdikleri önem, 49-58 yaş grubunda ( A.0.= 4.66) ve 59 yaş ve üzeri (A.0.= 4.62) yer alan bireylerden anlamlı bir şekilde farklılaştığ tespit edilmiştir. Buna göre 18-28 yaş grubundaki bireyler güvenlik değişkenine 49-59 ve 59 ve üzeri yaş grubundaki bireylerden daha çok önem vermektedir. Genç yaş grubundaki bireylerin orta ve ileri yaş grubundaki bireylere nazaran banka tercih ederken güvenlik değişkenine daha fazla önem verdikleri ifade edilebilir. Hipotez 2: "Yaş arttıkça banka tercihinde güvenlik değişkenine verilen önem artmaktadır" biçiminde belirlenmiştir. Bulgulardan hareketle genç yaş grubundaki bireylerin (18-28 yaş), güvenlik değişkenine 
diğer yaş gruplarına göre daha çok önem verdikleri belirlenmiştir. $\mathrm{Bu}$ nedenle hipotez 2, reddedilmiștir.

Çoklu karşılaștırma tablosuna bakıldığında 18-28 yaş grubunda (A.0.= 4.59) yer alan bireylerin kurumsal iletişim değişkenine verdikleri önem diğer tüm yaş grupları ile farklılaştığı görülmektedir. Buna göre 18-28 yaş grubundaki bireyler diğer tüm yaş grubundaki bireylere nazaran banka tercihlerinde kurumsal iletişim değișkenine daha çok önem vermektedir.

Kurumsal sosyal sorumluluk değişkeninde 18-28 yaş grubunda (A.O.= 4.39) yer alan bireyler kurumsal sosyal sorumluluk değişkenine 59 yaş ve üzeri dışındaki tüm yaş gruplarından anlamlı olarak farklılaşmakta ve bu değişkene daha fazla önem vermektedir. Bu durum değerlendirildiğine gençlerin banka tercihlerinde bankaların sosyal sorumluluk çalışmalarını önemsedikleri ifade edilebilir.

\subsection{Bankaların İmajında Etkili Olan Unsurlar ile Eğitim Durumu}

Tablo 4: Banka İmajı Oluşumunda Rolü Olan Değişkenler İle Eğitim Durumu

\begin{tabular}{|c|c|c|c|c|}
\hline FAKTÖRLER & EĞiTiM DURUMU & ORTALAMA & F Testi & P Değeri \\
\hline \multirow{4}{*}{ Güvenlik } & İlkokul & 4.55 & \multirow{4}{*}{9.45} & \multirow{4}{*}{.000} \\
\hline & Ortaokul & 4.75 & & \\
\hline & Lise & 4.81 & & \\
\hline & Üniversite & 4.88 & & \\
\hline \multirow{4}{*}{ Kurumsal Davranış } & İlkokul & 4.71 & \multirow{4}{*}{1.21} & \multirow{4}{*}{.305} \\
\hline & Ortaokul & 4.76 & & \\
\hline & Lise & 4.83 & & \\
\hline & Üniversite & 4.81 & & \\
\hline \multirow{4}{*}{ Kurumsal İletişim } & illkokul & 4.32 & \multirow{4}{*}{11.5} & \multirow{4}{*}{.000} \\
\hline & Ortaokul & 4.37 & & \\
\hline & Lise & 4.35 & & \\
\hline & Üniversite & 4.59 & & \\
\hline \multirow{4}{*}{ Kurumsal Görünüm } & İlkokul & 4.35 & \multirow{4}{*}{3.20} & \multirow{4}{*}{.023} \\
\hline & Ortaokul & 4.35 & & \\
\hline & Lise & 4.48 & & \\
\hline & Üniversite & 4.52 & & \\
\hline \multirow{4}{*}{$\begin{array}{l}\text { Kurumsal } \\
\text { Sosyal Sorumluluk }\end{array}$} & İlkokul & 3.97 & \multirow{4}{*}{10.7} & \multirow{4}{*}{.000} \\
\hline & Ortaokul & 4.17 & & \\
\hline & Lise & 4.11 & & \\
\hline & Üniversite & 4.38 & & \\
\hline
\end{tabular}

Güvenlik, kurumsal davranıș, Kurumsal İletişim, Kurumsal Görünüm ve Kurumsal Sosyal Sorumluluk değişkenlerinin araştırmaya katılanların eğitim durumlarına göre farklılaşıp farklılaşmadığını test etmek amacıyla tek yönlü varyans analizi (ANOVA) uygulanmıștır. Tablo-4'te ayrıntılı olarak sunulan sonuçlar incelendiğinde, güvenlik ( $F=9.45 ; \mathrm{p}<.05)$; kurumsal iletişim ( $\mathrm{F}=11.5 ; \mathrm{p}<.05)$; kurumsal görünüm $(\mathrm{F}=3.20 ; \mathrm{p}<.05)$ ve kurumsal sosyal sorumluluk ( $\mathrm{F}=10.7 ; \mathrm{p}<.05)$ katılımcıların yaşına göre anlamlı bir şekilde farklılaşan değişkenler olarak tespit edilmiştir. Kurumsal davranış değişkeni ( $F=1.21$; p>.05) ile katılımcıların eğitim durumları arasında anlamlı bir ilişki tespit edilememiştir.

Hangi eğitim durumları arasında farklılaşma olup olmadığını tespit etmek için Tukey testi yapılmıştır. Çoklu karşılaştırma tablosuna bakıldığında lise (A.0.= 4.81) ve üniversite (A.O.= 4.88) eğitim düzeyine sahip olan bireylerin ilkokul (A.0.= 4.55) 
eğitim düzeyindeki bireylere nazaran banka tercihlerinde güvenliğe daha fazla önem verdikleri değerlendirilmiştir.

Üniversite eğitim düzeyindeki bireyler (A.0.= 4.59) diğer eğitim düzeyindeki bireylere nazaran banka tercihlerinde bankaların kurumsal iletişim faaliyetlerine daha fazla önem verdikleri tespit edilmiştir.

Üniversite eğitim düzeyindeki bireyler (A.0.= 4.38); ilkokul (A.0.= 3.97) ve lise (A.0.= 4.11) eğitim düzeyine sahip olan bireylere nazaran banka tercihlerinde bankaların kurumsal sosyal sorumluluk faaliyetlerine daha fazla önem verdikleri tespit edilmiştir. Hipotez 3. "Eğitim düzeyi arttıkça banka tercihinde etkili olan sosyal sorumluluk faaliyetlerine verilen önem artmaktadır" biçiminde ifade edilmiştir. Elde edilen sonuçlara göre hipotez 3, kabul edilmiştir. Sosyal sorumluluk faaliyetlerine verilen önem düzeyinin artışında alınan eğitimin etkili olduğu değerlendirilebilir. Bu nedenle bu sonuç öngörülen bir bulgudur.

Kurumsal görünümle ilgili çoklu karşılaștırma tablolarına bakıldığında eğitim düzeyi ile banka tercihinde etkili olan değişkenler arasındaki farklılaşmanın kaynağı tespit edilememiştir.

\subsection{Bankaların İmajında Etkili Olan Unsurlar ile Aylık Harcama Miktarı}

Tablo 5: Banka İmajı Oluşumunda Rolü Olan Değişkenler İle Yaş Durumu

\begin{tabular}{|c|c|c|c|c|}
\hline FAKTÖRLER & AYLIK HARCAMA MIKTARI & ORTALAMA & F Testi & P Değer \\
\hline \multirow{4}{*}{ Güvenlik } & 2020 TL ve altı & 4.85 & \multirow{4}{*}{3.66} & \multirow{4}{*}{.012} \\
\hline & 2021- $4000 \mathrm{TL}$ & 4.77 & & \\
\hline & 4001-6000 TL & 4.89 & & \\
\hline & 6001 TL ve üzeri & 4.61 & & \\
\hline \multirow{4}{*}{ Kurumsal Davranış } & 2020 TL ve altı & 4.83 & \multirow{4}{*}{2.78} & \multirow{4}{*}{.040} \\
\hline & 2021- 4000 TL & 4.76 & & \\
\hline & 4001-6000 TL & 4.82 & & \\
\hline & 6001 TL ve üzeri & 4.60 & & \\
\hline \multirow{4}{*}{ Kurumsal İletişim } & 2020 TL ve altı & 4.56 & \multirow{4}{*}{6.59} & \multirow{4}{*}{.000} \\
\hline & 2021- 4000 TL & 4.41 & & \\
\hline & 4001-6000 TL & 4.28 & & \\
\hline & 6001 TL ve üzeri & 4.51 & & \\
\hline \multirow{4}{*}{$\begin{array}{l}\text { Kurumsal } \\
\text { Görünüm }\end{array}$} & 2020 TL ve altı & 4.52 & \multirow{4}{*}{1.83} & \multirow{4}{*}{.140} \\
\hline & 2021- $4000 \mathrm{TL}$ & 4.44 & & \\
\hline & 4001-6000 TL & 4.39 & & \\
\hline & 6001 TL ve üzeri & 4.35 & & \\
\hline \multirow{4}{*}{$\begin{array}{l}\text { Kurumsal } \\
\text { Sosyal Sorumluluk }\end{array}$} & 2020 TL ve altı & 4.35 & \multirow{4}{*}{4.65} & \multirow{4}{*}{.003} \\
\hline & 2021- $4000 \mathrm{TL}$ & 4.16 & & \\
\hline & 4001-6000 TL & 4.16 & & \\
\hline & 6001 TL ve üzeri & 4.09 & & \\
\hline
\end{tabular}

Güvenlik, kurumsal davranıș, Kurumsal İletişim, Kurumsal Görünüm ve Kurumsal Sosyal Sorumluluk değişkenlerinin araştırmaya katılanların aylık harcama miktarına göre farklılaşıp farklılaşmadığını test etmek amacıyla tek yönlü varyans analizi (ANOVA) uygulanmıştır. Tablo-5'te ayrıntılı olarak sunulan sonuçlar incelendiğinde, güvenlik ( $\mathrm{F}=3.66$; $\mathrm{p}<.05$ ); kurumsal davranıș ( $\mathrm{F}=2.78 ; \mathrm{p}<.05)$; kurumsal iletișim ( $\mathrm{F}=6.59 ; \mathrm{p}<.05$ ) ve kurumsal sosyal sorumluluk ( $\mathrm{F}=4.65 ; \mathrm{p}<.05)$ katılımcıların aylık harcama miktarına göre anlamlı bir şekilde farklılaşan değişkenler olarak tespit edilmiştir. Kurumsal 
görünüm değişkeni ( $\mathrm{F}=1.83 ; \mathrm{p}>.05)$ ile katılımcıların aylık harcama miktarı arasında anlamlı bir ilişki tespit edilememiştir.

Hangi aylık harcama miktarı arasında farklılaşma olup olmadığını tespit etmek için Tukey testi yapılmıştır. Çoklu karşılaştırma tablosuna bakıldığında katılımcıların aylık harcama miktarı ile banka tercihlerinde etkili olan değişkenlerden güvenlik ve davranış değişkenlerinde farklılaşmanın kaynağı tespit edilememiştir.

Bununla birlikte 2020 TL ve altı (A.0.= 4.35) aylık harcama miktarına sahip olan katılımcıların 2021-4000 TL (A.O.= 4.16) gelire sahip olan katılımcılara nazaran kurumsal sosyal sorumluluk çalışmalarında banka tercihlerinde daha fazla önem verdikleri belirlenmiştir.

Ayrıca 2020 TL ve altı (A.0.= 4.56) aylık harcama miktarına sahip olan katılımcıların 2021-4000 TL (A.0.= 4.41) ve 4001-6000 TL (A.04.28) gelire sahip olan katılımclara nazaran kurumsal iletişim çalışmalarına banka tercihlerinde daha fazla önem verdikleri belirlenmiştir.

\subsection{Bankaların İmajında Etkili Olan Unsurlar ile Meslek Durumu}

Tablo 6: Banka İmajı Oluşumunda Rolü Olan Değişkenler İle Meslek Durumu

\begin{tabular}{|c|c|c|c|c|}
\hline FAKTÖRLER & MESLEK & ORTALAMA & F Testi & P Değeri \\
\hline \multirow{10}{*}{ Güvenlik } & İşçi & 4.73 & \multirow{10}{*}{4.15} & \multirow{10}{*}{.000} \\
\hline & Memur & 4.91 & & \\
\hline & Esnaf & 4.84 & & \\
\hline & Serbest Meslek & 4.84 & & \\
\hline & Emekli & 4.67 & & \\
\hline & Sanayici-Tüccar & 5.00 & & \\
\hline & Ev Hanımı & 4.57 & & \\
\hline & Öğrenci & 4.89 & & \\
\hline & Öğretmen & 4.86 & & \\
\hline & İşsiz & 5.00 & & \\
\hline \multirow{10}{*}{ Kurumsal İletişim } & İşçi & 4.51 & \multirow{10}{*}{5.78} & \multirow{10}{*}{.000} \\
\hline & Memur & 4.50 & & \\
\hline & Esnaf & 4.28 & & \\
\hline & Serbest Meslek & 4.37 & & \\
\hline & Emekli & 4.26 & & \\
\hline & Sanayici-Tüccar & 4.01 & & \\
\hline & Ev Hanımı & 4.32 & & \\
\hline & Öğrenci & 4.61 & & \\
\hline & Öğretmen & 4.48 & & \\
\hline & İşsiz & 4.56 & & \\
\hline
\end{tabular}




\begin{tabular}{|c|c|c|c|c|}
\hline \multirow{10}{*}{ Kurumsal Sosyal Sorumluluk } & İşçi & 4.15 & \multirow{10}{*}{5.61} & \multirow{10}{*}{.000} \\
\hline & Memur & 4.05 & & \\
\hline & Esnaf & 4.24 & & \\
\hline & Serbest Meslek & 4.30 & & \\
\hline & Emekli & 4.14 & & \\
\hline & Sanayici-Tüccar & 3.84 & & \\
\hline & Ev Hanımı & 4.03 & & \\
\hline & Öğrenci & 4.43 & & \\
\hline & Öğretmen & 4.54 & & \\
\hline & İşsiz & 3.56 & & \\
\hline
\end{tabular}

Güvenlik, kurumsal davranıș, Kurumsal İletişim, Kurumsal Görünüm ve Kurumsal Sosyal Sorumluluk değişkenlerinin araştırmaya katılanların meslek gruplarına göre farklılaşıp farklılaşmadığını test etmek amacıyla tek yönlü varyans analizi (ANOVA) uygulanmıştır. Tablo-6'da ayrıntılı olarak sunulan sonuçlar incelendiğinde, güvenlik ( $\mathrm{F}=; 4.15 \mathrm{p}<$ .05); kurumsal iletişim ( $F=5.78 ; p<.05)$ ve kurumsal sosyal sorumluluk ( $F=5.61 ; p<$ .05) katılımcıların meslek gruplarına göre anlamlı bir şekilde farklılaşan değişkenler olarak tespit edilmiștir. Kurumsal görünüm değișkeni ( $F=1.14 ; p>.05)$ ve kurumsal davranış ( $\mathrm{F}=$; $1.45 ; \mathrm{p}>.05$ ) ile katılımcıların meslek grupları arasında anlamlı bir ilişkiye rastlanmamıştır.

Katılımcıların meslek grupları ile banka tercihinde etkili olan değişkenler arasında farklılaşma olup olmadığını tespit etmek için Tukey testi yapılmıştır. Öğrenciler (A.0.= 4.43), işçi (A.0.= 4.15), memur (A.0.=4.05), sanayici-tüccar (A.0.=3.84) ve ev hanımlarına (A.0.= 4.03) nazaran banka tercihlerinde bankaların gerçekleştirmiş olduğu sosyal sorumluluk çalışmalarına daha fazla önem verdikleri görülmektedir.

Bununla birlikte işçi (A.0.= 4.51) ve memurlar (A.0.=4.50), sanayici-tüccar (A.0.=4.01) meslek grubundaki katılımclara nazaran kurumsal iletişim faaliyetlerine daha fazla önem vermektedir. Öğrenciler ise (A.0.= 4.61), esnaf (A.0.=4.28), emekli (A.0.= 4.26), sanayici-tüccar (A.0.= 4.01) ve ev hanımlarına (A.0.= 4.32) nazaran banka tercihlerinde bankaların kurumsal iletişim faaliyetlerini daha fazla önemsedikleri belirlenmiștir.

Memurlar (A.O.=4.91), ev hanımlarına (A.0.=4.57) nazaran banka tercihlerinde güvenlik değişkenine daha fazla önem vermektedirler. Ayrıca öğrenciler (A.0.= 4.89), işçi (A.O.= 4.73) ve ev hanımlarına (A.O.= 4.57) nazaran banka tercihlerinde güvenlik değişkenine daha fazla önem atfetmektedirler.

\subsection{Bankaların İmajında Etkili Olan Unsurlar ile Kredi Kartı Sahipliği t-Testi Sonuçları}

$\mathrm{Bu}$ başlık altında bankaların imajında etkili olan değişkenlere verilen önem düzeyinin kredi kartı sahipliğine göre farklılaşıp farklılaşmadığını belirlemek için yapılan bağımsız örneklem t-testi sonuçlarına yer verilecektir. Bu sonuçlar Tablo-7'de gösterilmektedir.

Tablo 7: Banka İmajı Oluşumunda Rolü Olan Değişkenler İle Kredi Kartı Sahipliği

\begin{tabular}{|c|c|c|c|c|}
\hline FAKTÖRLER & KREDI KARTI SAHIPLIĞi & ORTALAMA & t-testi & P değeri \\
\hline \multirow{2}{*}{ Güvenlik } & Var & 4.86 & \multirow{2}{*}{3.35} & \multirow{2}{*}{.001} \\
\hline & Yok & 4.74 & & \\
\hline \multirow{2}{*}{ Kurumsal Davranış } & Var & 4.81 & \multirow{2}{*}{.972} & \multirow{2}{*}{.331} \\
\hline & Yok & 4.78 & & \\
\hline
\end{tabular}




\begin{tabular}{|c|c|c|c|c|}
\hline FAKTÖRLER & KREDI KARTI SAHIPLIĞi & ORTALAMA & t-testi & $P$ değeri \\
\hline \multirow{2}{*}{ Kurumsal İletişim } & Var & 4.48 & \multirow{2}{*}{-.843} & \multirow{2}{*}{.400} \\
\hline & Yok & 4.52 & & \\
\hline \multirow{2}{*}{ Kurumsal Görünüm } & Var & 4.51 & \multirow{2}{*}{1.99} & \multirow{2}{*}{.047} \\
\hline & Yok & 4.42 & & \\
\hline \multirow{2}{*}{ Kurumsal Sosyal Sorumluluk } & Var & 4.29 & \multirow{2}{*}{.966} & \multirow{2}{*}{.334} \\
\hline & Yok & 4.23 & & \\
\hline
\end{tabular}

Bankaların kurumsal imaj oluşumunda etkili olan değișkenlere verilen önem düzeyinin kredi kartı sahipliğine göre farklılaşıp farklılaşmadığını belirlemek için bağımsız örneklem t testi yapılmıştır. Bu teste göre yalnızca güvenlik ve kurumsal görünüm değişkenlerinin kredi kartı sahipliğine göre farklılaştıkları tespit edilmiştir $(\mathrm{p}<0.05)$. Buna göre güvenlik değişkenine kredi kartına sahip olanların verdiği önem düzeyi (A.0 = 4.86) kredi kartına sahip olmayanların verdiği önem düzeyinden ( A.O =4.74) daha yüksektir. Hipotez 4. "Kredi kartı sahip olan bireyler, banka tercihinde güvenlik değișkenine daha fazla önem vermektedir." şeklinde belirlenmiştir. Elde edilen bulgulara göre hipotez 4, doğrulanmıştır. Medyada yer verilen siber saldırı ve dolandırıcılık gibi tehditlere yönelik haberlerin bu yöndeki kaygıları arttırdığı, dolayısıyla böyle bir sonucun çıkması da beklenen bir durumdur.

Ayrıca kurumsal görünüm değişkenine kredi kartına sahip olanların verdiği önem düzeyi (A.O.= 4.51) kredi kartına sahip olmayanların (A.O.= 4.42) verdiği önem düzeyinden daha yüksek olduğu belirlenmiștir. Kredi kartına sahip olanların güvenlik değişkenine daha fazla önem vermeleri beklenen bir sonuçtur. Bu bulgudan hareketle bankaların müşterilerine hizmet sunarken güvenlik unsuruna ilişkin çalışmalar gerçekleștirmeleri ve bundan mevcut ve potansiyel müşterilerini haberdar etmeleri bankaların tercih edilmesi açısından önemlidir. Bu ise bankaların kurumsal imajına olumlu yönde etki edecektir.

\subsection{Bankaların İmajında Etkili Olan Unsurlar ile Hizmet Alma Biçimi}

Tablo 8: Banka İmajı Oluşumunda Rolü Olan Değişkenler İle Bankadan Hizmet Alma Biçimi

\begin{tabular}{|c|c|c|c|c|}
\hline FAKTÖRLER & $\begin{array}{l}\text { BANKALARDAN HiZMET } \\
\text { ALMA Biçimi }\end{array}$ & ORTALAMA & F Testi & P Değeri \\
\hline \multirow{4}{*}{ Güvenlik } & Banka Şubesi & 4.61 & \multirow{4}{*}{8.60} & \multirow{4}{*}{.000} \\
\hline & ATM & 4.79 & & \\
\hline & İnternet Bankacılığı & 4.87 & & \\
\hline & Mobil Uygulamalar & 4.90 & & \\
\hline \multirow{4}{*}{ Kurumsal Davranış } & Banka Şubesi & 4.81 & \multirow{4}{*}{.821} & \multirow{4}{*}{.483} \\
\hline & ATM & 4.76 & & \\
\hline & İnternet Bankacılığı & 4.82 & & \\
\hline & Mobil Uygulamalar & 4.83 & & \\
\hline \multirow{4}{*}{ Kurumsal İletişim } & Banka Şubesi & 4.33 & \multirow{4}{*}{7.94} & \multirow{4}{*}{.000} \\
\hline & ATM & 4.45 & & \\
\hline & İnternet Bankacılığı & 4.61 & & \\
\hline & Mobil Uygulamalar & 4.44 & & \\
\hline \multirow{4}{*}{ Kurumsal Görünüm } & Banka Şubesi & 4.44 & \multirow{4}{*}{3.44} & \multirow{4}{*}{.017} \\
\hline & ATM & 3.39 & & \\
\hline & İnternet Bankacııı̆ı & 4.56 & & \\
\hline & Mobil Uygulamalar & 4.50 & & \\
\hline
\end{tabular}




\begin{tabular}{|l|l|c|c|c|}
\hline \multirow{2}{*}{ FAKTÖRLER } & $\begin{array}{l}\text { BANKALARDAN HIZMET } \\
\text { ALMA Biçimi }\end{array}$ & ORTALAMA & F Testi & \multirow{2}{*}{ P Değeri } \\
\hline \multirow{3}{*}{$\begin{array}{l}\text { Kurumsal } \\
\text { Sosyal Sorumluluk }\end{array}$} & Banka Şubesi & 4.04 & \\
\cline { 2 - 3 } & ATM & 4.25 & \multirow{2}{*}{4.25} & .005 \\
\cline { 2 - 3 } & İnternet Bankacılığı & 4.32 & \\
\cline { 2 - 3 } & Mobil Uygulamalar & 4.34 & \\
\hline
\end{tabular}

Güvenlik, kurumsal davranış, Kurumsal İletişim, Kurumsal Görünüm ve Kurumsal Sosyal Sorumluluk değişkenlerinin araştırmaya katılanların bankalardan hizmet alma biçimlerine göre farklılaşıp farklılaşmadığını test etmek amacıyla tek yönlü varyans analizi (ANOVA) uygulanmıştır. Tablo-8' de ayrıntılı olarak sunulan sonuçlar incelendiğinde, güvenlik ( $\mathrm{F}=$; $8.60 \mathrm{p}<.05)$; kurumsal iletişim ( $\mathrm{F}=7.94 ; \mathrm{p}<.05)$ ve kurumsal sosyal sorumluluk ( $\mathrm{F}=4.25$; $\mathrm{p}<.05$ ) katılımcıların bankalardan hizmet alma biçimlerine göre anlamlı bir şekilde farklılaşan değişler olarak tespit edilmiştir. Kurumsal görünüm ( $\mathrm{F}=3.44 ; \mathrm{p}>.05)$ ve kurumsal davranış ( $\mathrm{F}=; .821 ; \mathrm{p}>.05$ ) değișkenleriyle katılımcıların bankalardan hizmet alma biçimleri arasında anlamlı bir ilişkiye rastlanmamıștır.

Katılımcıların bankalardan hizmet alma biçimleri ile banka tercihinde etkili olan değişkenler arasında farklılaşma olup olmadığını tespit etmek için Tukey testi yapılmıştır. Banka hizmetini ATM üzerinden alanlar (A.0.= 4.43), internet bankacılığ $($ A.0.= 4.15), mobil uygulamalar üzerinden alanlar, bu hizmeti bizzat banka şubelerine giderek alanlara nazaran (A.0.= 4.05), güvenlik değişkenine daha çok önem vermektedirler. Bu sonuca göre "Yeni iletişim teknolojileri üzerinden bankacılık hizmeti alanlar güvenlik değişkenine daha fazla önem vermektedir", şeklinde ifade edilen hipotez 5, doğrulanmıştır. Böylece ATM, internet bankacılığı ve mobil uygulamalar üzerinden gerçekleştirilen siber suçlar ve yaşanan mağduriyetlerin önüne geçilebilmesi ve bu yönde banka müşterilerinin algılarının olumlu anlamda motive edilebilmesi için bankaların bu hizmetleri sunarken güvenlik değişkenini oluşturan unsurları daha fazla göz önünde bulundurması gerekliliği ifade edilmelidir.

Katılımcılardan internet bankacılığı ile banka hizmetlerine erișim sağlayanlar (A.0.= 4.61) banka şubesi (A.0.= 4.33), mobil uygulamalar (A.0.=4.44) ve ATM (A.0.=4.45) aracılığıyla banka hizmetlerine erişim sağlayanlara nazaran kurumsal iletişim faaliyetlerine daha fazla önem vermektedirler. Bu bulgu internet bankacılığı yoluyla banka hizmetlerine erişim sağlayanlara dönük özellikle bankaların kurumsal web sayfalarından daha etkin bir biçimde yararlanmaları gerektiğini ortaya koyması açısından önemlidir.

İnternet bankacılığı (A.O.= 4.32) ve mobil uygulamalar (A.0.= 4.34) aracılığıyla banka hizmetlerine erişim sağlayan katılımcılar, banka şubelerinden (A.O.= 4.04) banka hizmetlerine erişim sağlayan katılımcılara nazaran kurumsal sosyal sorumluluk faaliyetlerine banka tercihlerinde daha fazla önem vermektedirler.

\subsection{Bankaların İmajında Etkili Olan Unsurlar Arasındaki İlişki}

Tablo-9'da bankaların imajında rolü olan değişkenler arasındaki ilişkinin yönü ve düzeyini tanımlamak açısından yapılan korelasyon analizi sonuçları yer almaktadır. Analiz sonuçları incelendiğinde, en güçlü ilişskinin güvenlik değişkeni ile kurumsal davranış değișkeni arasında olduğu görülmektedir ( $r=.763, p<.01)$. Diğer bir ifadeyle güvenlik değişskeni ve kurumsal davranış değișkeni arasında pozitif yönde yüksek düzeyde ve anlamlı bir ilişki bulunmaktadır. Bu bulgu bankaların güvenlik unsurlarını önem vermeleri yanında kurumsal davranış değişkenini oluşturan unsurlara da gerekli 
hassasiyeti göstermelerine işaret etmektedir. Banka çalışanlarının müşterilerine davranış biçimlerine güvenilir kurum imajına etki ederek olumlu yönde pekiştirecektir.

Tablo 9: Banka İmajı Oluşumunda Rolü Olan Değişkenlere İlişkin Korelasyon Analizi Bulguları

\begin{tabular}{|c|c|c|c|c|c|}
\hline \multicolumn{6}{|c|}{ Correlations } \\
\hline & $\begin{array}{l}\text { Kurumsal } \\
\text { Görünüm }\end{array}$ & $\begin{array}{c}\text { Kurumsal } \\
\text { Sosyal } \\
\text { Sorumluluk }\end{array}$ & $\begin{array}{c}\text { Kurumsal } \\
\text { İletişim }\end{array}$ & $\begin{array}{c}\text { Kurumsal } \\
\text { Davranış }\end{array}$ & Güvenlik \\
\hline Kurumsal Görünüm & 1 & $478^{\star \star}$ &, $507^{\star *}$ &, $503^{\star *}$ &, $407^{\star \star}$ \\
\hline Kurumsal Sosyal Sorumluluk & $478^{\star \star}$ & 1 &, $439 * *$ &, $295^{\star *}$ & ,269** \\
\hline Kurumsal İletişim &, $507^{\star \star}$ &, $439^{\star \star}$ & 1 &, $408^{\star \star}$ &, $481^{* \star}$ \\
\hline Kurumsal Davranış &, $503^{\star \star}$ &, $295^{\star \star}$ &, $408^{\star *}$ & 1 &, $763^{\star \star}$ \\
\hline Güvenlik & $407^{\star \star}$ & ,269** &, $481^{\star \star}$ &, $763^{\star \star}$ & 1 \\
\hline
\end{tabular}

Kurumsal iletişim ile kurumsal görünüm değişkeni arasında ( $\mathrm{r}=.507, \mathrm{p}<.01)$, kurumsal sosyal sorumluluk ( $\mathrm{r}=.439, \mathrm{p}<.01)$; kurumsal davranış $(\mathrm{r}=.408, \mathrm{p}<.01)$ ve güvenlik değişkeni arasında $(\mathrm{r}=.481, \mathrm{p}<.01)$ pozitif yönde orta düzeyde ve anlamlı ilişki olduğu tespit edilmiştir.

Değişkenler arasındaki ilişki düzeyi diğer bir anlatımla, kurumsal iletişim değişkenine verilen önem arttıkça kurumsal görünüm, kurumsal sosyal sorumluluk, kurumsal davranış ve güvenlik değişkenine verilen önemde artmaktadır. $\mathrm{Bu}$ nedenle hizmet sektöründe faaliyet gösteren bankaların olumlu imaj oluşturmak için kurumsal iletişim faaliyetleri ile birlikte sırasıyla kurumsal görünüm, kurumsal sosyal sorumluluk, kurumsal davranış ve güvenlik pratiklerini de dikkate almaları büyük önem taşımaktadır.

Ayrıca bu çalışmanın amacına yönelik olarak yanıtı aranan araştırma soruları ise şu şekilde değerlendirilmiştir:

1. Bireylerin banka tercihine en çok rolü olan kurumsal imaj değişkeni nedir?

2. Katılımcıların değerlendirmelerine göre bireylerin banka tercihinde en çok rolü olan kurumsal imaj değişkeninin güvenlik unsuru olduğu belirlenmiștir. Buna göre bireylerin finansal anlamda en çok güvende olma kaygıları taşıdıkları kurumların başında gelen bankalar hedef kitleleri nezdinde daha çok olumlu bir kurumsal imajla algılanabilmek için güvenlik önlem ve uygulamalarına diğer kurumsal imaj değişkenlerine göre daha çok önem vermeleri ifade edilmelidir.

3. Banka tercihinde rolü olan kurumsal imaj değișkenleri arasında ne tür bir ilişki vardır?

4. Yapılan analizler neticesinde bankaların kurumsal imajında rolü olan kurumsal imaj değişkenleri arasında en güçlü ilişkinin güvenlik ve kurumsal davranış değişkeni arasında olduğu değerlendirilmiştir. Böylece güvenlik değişkenini önemseyen katılımcıların kurumsal davranışı da oldukça önemsedikleri ifade edilmelidir. $\mathrm{Bu}$ açıdan bankalar güvenlik uygulamalarına yönelik yürütecekleri faaliyetlerle birlikte kurumsal davranış şekillerine önem vermeleri gerektiği söylenebilir.

5. Banka tercihinde rolü olan maddelerin önem düzeyleri nedir?

6. Banka tercihinde rolü olan maddeler önem düzeyine göre ilk beş madde; banka personelinin güvenilir olması, banka ATM'lerinin güvenli olması, banka personelinin müşterilere anlayışlı davranması, banka çalışanlarının müşteri şikayetlerini dikkate almaları ve banka çalışanlarının müşterilerle saygılı konuşmaları şeklinde 
sıralanmıştır. Önem düzeyine göre son beș madde ise; ATM'ler modern bir görünüşe sahip olmalıdır, banka medyada olumlu haberlerle yer almalıdır, bankalar kültür- sanat faaliyetlerini desteklenmelidir, bankaların çeşitli alanlarda sponsorluk faaliyetleri olmalıdır, bankaların çeşitli alanlarda sponsorluk faaliyetleri olmalıdır şeklinde sıralanmıştır. Ancak bu maddeler önem sırası bakımından son sırada yer alsa da, maddelerin ortalama değerleri 4 ve 4 üzerindedir. Bu nedenle bankalar kurumsal imajlarına yönelik olarak yapacakları faaliyet ve uygulamalarda bu maddelerde işaret edilen hususları da göz önünde bulundurmaları ifade edilmelidir.

7. Banka tercihinde halkla ilişkiler çalışmalarının rolü ve önemi nedir?

8. Halkla ilișkiler faaliyetleri olmadan bankalar hedef kitleleri üzerinde istendik yönlendirme ve algıyı oluşturamazlar. Bu nedenle katılımcıların özellikle bankalardan beklentileri olan güvenlik değişkeni hususu bulgusuna yönelik bankaların halkla ilişkiler araç ve yöntemlerini kullanarak hedef kitlelerinde güven algısını olumlu hale getirecek ve bunu koruyacak politikalar izlemeleri ifade edilmelidir. Ayrıca bu çalışma kapsamında kurumsal imaj belirleyicisi olarak belirlenen yargıların işaret ettiği uygulamalar olan ancak halkla ilişkiler kapsamında gerçekleştirilebilir. Bu sebeple halkla ilişkileri etkin şekilde kullanamayan bankaların kurumsal imaj bağlamında da zorluklar yaşayabileceği ifade edilmelidir.

9. Katılımcıların bankalardan hizmet alma biçimleri nelerdir?

10. Katılımcıların en çok internet bankacılığı yoluyla bankalarından hizmet aldığı değerlendirilmiştir. Bu açıdan bankalar hedef kitlelerini nezdinde olumlu algılanmaya yönelik girişimlerinde internet bankalılığı faaliyetlerini sürekli güncellemelidir.

\section{Sonuç}

Günümüz rekabet ortamında hizmet sektöründe yer alan kuruluşların kaliteli ürün veya hizmeti uygun fiyata sunmaları yeterli değildir. Hedef kitlesine uygun fiyata kaliteli ürün veya hizmet sunma yanında kuruluşlar, gerçekleştirecekleri halkla ilişkiler uygulamaları ile olumlu bir algı da oluşturmaları gerekmektedir. Kuşkusuz bunda kurumsal imaj çalışmaları ve kurumsal imajı oluşturan bir takım bileşenlerin rolü büyüktür.

Hizmet sektöründe yer alan bankaların ise olumlu algı oluşturmada diğer kuruluşlara nazaran daha fazla bu enstrümanlardan doğru bir biçimde yararlanması gerekmektedir. Finansal faaliyetlerin aktörü olan bankalar için başta güven olmak üzere, kurumsal davranış, kurumsal iletişim, kurumsal görüntü ve kurumsal sosyal sorumluluk çalışmalarına önem vermeleri günümüzde bir zorunluluktur.

Bankaların tercih edilmesinde hedef kitleyi motive eden unsurları belirlemek üzere Konya merkezde 558 kişi üzerinde gerçekleștirilen araștırmanın temel bulguları şöyledir:

Banka tercihlerinde katılımcılar sırasıyla güvenlik, kurumsal davranış, kurumsal iletișim, kurumsal görünüm ve kurumsal sosyal sorumluluk uygulamalarını göz önünde bulundurarak karar vermektedirler.

Hizmet aldıkları bankalarla ilgili haberleri katılımcılar sırasıyla internet, televizyon, sosyal medya, gazete ve dergi mecralarından aldıkları belirlenmiştir.

Bankalardan hizmet alma biçimlerine bakıldığında internet bankacılığı birinci sırada yer almaktadır. Bunu ATM, mobil uygulamalar ve bizzat banka şubesine giderek hizmet alma takip etmektedir. 
18-28 yaş grubunda yer alan bireyler, diğer yaş gruplarına nazaran güvenlik, kurumsal iletişim ve kurumsal sosyal sorumluluk faaliyetlerine daha çok önem vermektedir.

Üniversite eğitim düzeyindeki katılımcılar, güvenlik, kurumsal iletişim ve kurumsal sosyal sorumluluk uygulamalarına diğer eğitim düzeyindeki bireylere göre daha fazla önem atfetmektedirler.

2020 TL ve altı aylık ortalama harcama miktarına sahip olan katılımcılar, diğer harcama miktarına sahip bireylere nazaran kurumsal iletişim ve kurumsal sosyal sorumluluğa daha çok değer vermektedirler.

Öğrenciler, diğer meslek gruplarına nazaran bankaların kurumsal iletişim ve kurumsal sosyal sorumluluk çalışmalarını daha çok önemsemektedirler.

Kredi kartına sahip olan katılımcılar, kredi kartına sahip olmayan bireylere nazaran güvenlik ve kurumsal sosyal sorumluluk çalışmalarını banka tercihinde daha fazla göz önünde bulundurmaktadırlar.

İnternet bankacılığı, mobil bankacılık ve ATM aracılığıyla bankacılık hizmetlerinden yararlanan katılımcılar, bizzat banka şubesine giderek hizmet alan bireylere nazaran güvenlik değişkenine daha fazla önem vermektedirler.

Bulgular değerlendirildiğinde 18-25 yaş grubundaki -çoğunlukla da üniversite öğrencisibireylerin, kredi kartına sahip olan katılımcıların ve bankacılık hizmetlerini online olarak alan banka müșterilerinin banka tercihlerinde güvenlik değişkeninin önemli olduğu belirlenmiştir. Özellikle bankaların müşterilerine güven telkin edici halkla ilişkiler çalışma ve stratejilerine önem vermeleri gerekmektedir. Hizmet sektöründe önem bir yere sahip olan bankaların bunu gerçekleştirebilmeleri ise, kurumsal iletişim, kurumsal davranış ve kurumsal görünümü kapsayan doğru halkla ilişkiler politikalarıyla mümkün olabilecektir.

\section{Kaynakça}

Abratt, R. (1989). A new approach to the corporate image management process. Journal of Marketing Management, 5(1), 63-76.

Alessandri, S. W. (2001). Modeling corporate identity: a concept explication and theoretical explanation. Corporate Communications: An International Journal, 6(4), 173-182.

Aslan, E. ve Aydın, C. (2018). Kurumsal sosyal sorumluluk faaliyetlerinin marka tercihine etkisi üzerine bir araştırma. Selçuk Üniversitesi İletişim Fakültesi Akademik Dergisi, 11 (1), 146-166.

Bakan, Ö. (2011). Kurumsal kimlik ve imaj. A. Kalender ve M. Fidan (Ed.), Halkla ilişkiler içinde (289-310). Konya: Tablet Kitabevi.

Bakan, Ö. (2005). Kurumsal imaj. Konya: Tablet Kitabevi.

Balcı, A. (2004). Sosyal bilimlerde araştırma: yöntem teknik ve ilkeler. Ankara: Pegem Akademi.

Balmer, J. M. (1998). Corporate identity and the advent of corporate marketing. Journal of Marketing Management, 14(8), 963-996. 
Balmer, J. M. (2008). Identity based views of the corporation: insights from corporate identity, organisational identity, social identity, visual identity, corporate brand identity and corporate image. European Journal of Marketing, 42(9/10), 879-906.

Bilbil, E. K. (2012). Kurumsal iletişim aracı olarak web sayfalarının kamu ve özel sektör kuruluşlarında karşılaştırmalı analizi. İstanbul Üniversitesi İletişim Fakültesi Dergisi,(32).

Bravo, R., Montaner, T., ve Pina, J. M. (2009). The role of bank image for customers versus non-customers. International Journal of Bank Marketing, 27(4), 315-334.

Brexendorf, T. O. ve Kernstock, J. (2007). Corporate behaviour vs brand behaviour: towards an integrated view?. Journal of Brand Management, 15(1), 32-40.

Carroll, A. B. (1979). A three-dimensional conceptual model of corporate performance. Academy of Management Review, 4(4), 497-505.

Castelo Branco, M., ve Lima Rodrigues, L. (2006). Communication of corporate social responsibility by portuguese banks: a legitimacy theory perspective. Corporate Communications: An International Journal, 11(3), 232-248.

Christensen,T.L.(2002).Corporatecommunication:thechallengeoftransparency.Corporate Communications: An International Journal, 7(3), 162-168.

Davies, G., Chun, R., da Silva, R. V. ve Roper, S. (2004). A corporate character scale to assess employee and customer views of organization reputation. Corporate Reputation Review, 7(2), 125-146.

Cian, L. ve Cervai, S. (2014). Under the reputation umbrella: an integrative and multidisciplinary review for corporate image, projected image, construed image, organizational identity, and organizational culture. Corporate Communications: An International Journal, 19(2), 182-199.

Çamdereli, M. (2015). İletişime giriş. İstanbul: Dem Yayınları.

Çerik, S. ve Özarslan, E. (2008). Çalışanların sosyal sorumluluk boyutlarına ilişkin algılamaları: ilaç sektöründe karşılaştırmalı bir uygulama. Ege Akademik Bakış Dergisi, 8(2), 587-604.

Çoban, H. ve İrmiş, A. (2018). Türkiye'de kurumsal sosyal sorumluluk faaliyetlerine ilişkin bir değerlendirme. Senem Nart ve Yavuz Tansoy Yıldırım (Editörler), Current Debates in Management and Organization içinde (s.65-80). London: IJOPEC Publication.

Doğan, S. Y. ve Varinli, İ. (2010). İşletmelerde sosyal sorumluluk anlayışı ve kurumsal imaj ilișkisi: banka müșterilerine yönelik bir araştırma. Ekonomik ve Sosyal Araştırmalar Dergisi, Güz, Cilt:6, Yıl:6, 2 (6), 1-26.

Doherty, A. J. (1998). Managing our human resources: A review of organisational behaviour in sport. Sport Management Review, 1(1), 1-24.

Dyck, A., Lins, K. V., Roth, L. ve Wagner, H. F. (2019). Do institutional investors drive corporate social responsibility? International evidence. Journal of Financial Economics, 131(3), 693-714.

Elden, M. (2005). Kurum kimliği ve kurumsal reklam arasındaki ilişki. Ege Üniversitesi İletişim Fakültesi Yeni Düşünceler Hakemli E-Dergisi, (1), 53-60. 
Foreman, J. ve Argenti, P. A. (2005). How corporate communication influences strategy implementation, reputation and the corporate brand: an exploratory qualitative study. Corporate Reputation Review, 8(3), 245-264.

Güllüpunar, H. ve Tekmen, T (2018). İmajın kurumsal itibara etkisi: Giresun Belediyesi örneği. Türkiye İletişim Araştırmaları Dergisi, (29), 89-110.

Güllüpunar, H. (2010). Halkla ilişkiler sosyal sorumluluk ilkesi: Kamu kuruluşları yaklaşımı bakımından Konya Büyük Şehir Belediyesi uygulama örnekleri. Gümüşhane Üniversitesi Sosyal Bilimler Enstitüsü Elektronik Dergisi, 1(1).

Gotsi, M. ve Wilson, A. M. (2001). Corporate reputation: seeking a definition. Corporate communications: An international journal, 6(1), 24-30.

Gray, E. R. ve Balmer, J. M. (1998). Managing corporate image and corporate reputation. Long range planning, 31(5), 695-702.

Gürbüz, S. (2017). Kurum İmajı Bileșenleri ve Belirleyicileri. Konya: Literatürkacademia.

Hatch, Jo M. ve Schultz, M. (1997). Relations between organizational culture, identity and image. European Journal of marketing, 31(5/6), 356-365.

Horng, J. S., Liu, C. H., Chou, S. F., Tsai, C. Y. ve Hu, D. C. (2018). Does corporate image really enhance consumer's behavioural intentions?. Asia Pacific Journal of Tourism Research, 23(10), 1008-1020.

Igbudu, N., Garanti, Z. ve Popoola, T. (2018). Enhancing bank loyalty through sustainable banking practices: the mediating effect of corporate image. Sustainability, 10(11), 4050, 1-11.

İlgüner, M. ve Asplund, C. (2011). Marka Şehir. İstanbul: Markating Yayınları.

İraz, R., Çetin, S. ve Karakoyun, B. E. (2012). Bankalarda halkla ilişkiler faaliyetlerinin performansa etkisi ve bir uygulama. SÜ IIBF Sosyal ve Ekonomik Araştırmalar Dergisi, 12(23), 201-240.

Karabey, C. N. ve Battal, F. (2018). Profesyonel etik standartlar, kurumsal sosyal sorumluluk. Atatürk Üniversitesi Sosyal Bilimler Enstitüsü Dergisi, 22(4), 2265-2286.

Kazancl, M. (2013). Kamuda ve özel kesimde halkla ilişkiler. Ankara: Turan Kitabevi.

Linkemer, B. (1997). Profesyonel imaj yaratmak. İstanbul: Rota Yayınları.

Margulies, W. P. (1977). Make most of your corporate identity. Harvard Business Review, 55(4), 66-74.

Mohamad, B., Nguyen, B., Melewar, T. C. ve Gambetti, R. (2019). The dimensionality of corporate communication management (CCM) A qualitative study from practitioners' perspectives in Malaysia. The Bottom Line, 32(1), 71-97.

Özdemir, İ. (2012). Bankacılıkta halkla ilişkiler ve müşteri ilişkileri. BSAD Bankacılık ve Sigortacılık Araştırmaları Dergisi, 1(3-4), 4-15.

Peltekoğlu, F. B. (2014). Halka ilişkiler nedir?. İstanbul:Beta.

Peltekoğlu, F. B. ve Tozlu, E. (2018). Kurumsal sosyal sorumluluk kampanyalarının dijital paydaşları; sosyal medya fenomenleri. Erciyes İletişim Dergisi, 5(4), 285-299.

Pira, A. (2005). Halkla ilişkiler için okumalar. İstanbul: Dönence.

Sayımer, İ. (2008). Sanal ortamda halkla ilişkiler. İstanbul: Beta Yayınları. 
Solmaz, B. (2005). İşletmelerin değișen konumuyla gelișen kurumsal sosyal sorumluluk bilinci ve Turkcellıin desteklediği "Çağdaş Türkiyeınin Çağdaş Kızları" projesinin genel bir değerlendirmesi. Selçuk Üniversitesi İletişim Fakültesi Akademik Dergisi, 4(1), 116-125.

Taburoğlu, Ö. (2013). Resim, söz ve yazı imge yaratmanın ve bozmanın Yolları (1.baskı). Ankara: Seçkin Yayıncılık.

Taşçı, D. ve Eroğlu, E. (2013). Kurumsal iletişim kalitesinin oluşmasında yöneticilerin geribildirim verme becerilerinin etkisi. Selçuk İletişim, 5 (2) , 26-34.

Thøger C. L. ve Askegaard, S. (2001). Corporate identity and corporate image revisited-A semiotic perspective. European journal of Marketing, 35(3/4), 292-315.

Tosun, N. (2003). Kurumsal iletişim sürecinde reklam ve imaj yönetiminin bütünleşik konumu. Marmara Üniversitesi İktisadi ve İdari Bilimler Dergisi, 18(1), 173-191.

Van Rekom, J. (1997). Deriving an operational measure of corporate identity. European Journal of Marketing, 31(5/6), 410-422.

Yavuz, A. N. (1972). Bankacılıkta halkla ilişkiler. İstanbul: Atak Matbaası.

Yazıcı, İ. (1997). Kitle iletişiminde imaj kuramsal bir yaklaşım. İstanbul: Bilim Yayınları.

Türkiye İstatistik Kurumu (2018). Nüfus ve demografi, Yıllara göre il nüfusları . Erişim adres:http://tuik.gov.tr/UstMenu.do?metod=temelist, Erişim tarihi: 25.03.2019. 


\title{
Public Relations Factors Affecting Bank Preferences: A Field Research on Corporate Image
}

\author{
Ahmet Tarhan (Assoc. Prof. Dr.)
}

Salih Gürbüz (Asst. Prof. Dr.)

\section{Extended Abstract}

Nowadays, as much as individuals, perceiving with a positive image is an important concern for the corporations built by individuals and which can exist with individuals. The perception of the corporations by their target audiences with positive images is undoubtedly possible by the fulfillment of certain conditions by the corporations. Although the image may be accidental, the effect of the image is too important to be left to random causes. A negligible image will cause disruptions in the vital functions of corporations. The continuation of the assets of the corporations is equivalent to the various meanings that individuals will attribute to the corporations.The creation of these meanings is within the scope of public relations. Corporations that give enough importance to public relations also attach importance to their image. The corporations benefiting from the various practices offered by public relations can make themselves positively accepted by their target audiences. Behind this acceptance is the corporate image. Corporate image; it can be expressed as the component of all kinds of concrete and intangible dimensions that the organization shows to its target audience. They are composed of wide components such as visual elements, culture, philosophy, behavior, communication and corporate responsibility activities. Perceptions created by these components on the target audience can determine the image of the organization. The behaviors and attitudes of the employees, who are the vital subjects and representatives of the corporations, also affect the image to be formed within the target audiences.

Banks which are financial corporations have an important role in the daily life of individuals. Banks are among the corporations most affected by global competition conditions. Therefore, banks have to engage in a wide range of activities and practices in order to impress both their existing customers and potential customers who will work with them. Among these practices, banks can influence their customers with social responsibility and sponsorship activities carried out to support social issues. Because, in today's corporate world, target audiences might wish to see such supports from all corporate structures. If the corporations convince their target groups that they are socially responsible organizations, they can increase their customer diversity and quantity more than their competitors. Furthermore, if banks use developing technologies to communicate more easily and quickly with their customers, they can be perceived positively by their customers. In addition, every kind of behavior of each bank employee towards each customer who comes to the bank is an important determinant for the customer. Gestures and facial expressions displayed by the bank's employees while providing services, and the way they talk to customers may be a positive or negative assessment criteria on the customer's mind. In addition, the facilities that can contribute to the positive perception of the target audiences such as car parks, visual guidance signs, air conditioning and lighting, which may be among the corporate appearance elements of the banks, are important for the corporate image of the banks. It is a subject of scientific interest for researchers to analyze how banks' images are perceived by the target audiences due to all these factors. 
The aim of this study is to investigate the determinants of the corporate image of financial institutions which are lacking in public relations literature. For this purpose, a field survey was conducted in Konya city center between the months of April and June 2019 by using face-to-face survey technique with 558 participants over 18 years of age.

When the findings of the study were evaluated that the participants give high importance to each of the factors such as security, behavior, corporate communication, visual identity and corporate social responsibility, respectively. In this respect, it is very important that banks should take into account the elements identified in the items presented within the framework of these factors. However, it was evaluated that the participants give the most importance to the items about the security of banks. Security is more important for banks than many corporations. For this reason, the importance level given to the security items by the participants should be taken into consideration by the banks for their corporate image. In addition, the behaviors of bank employees has been found to be a second corporate image determinant, which is as important as the security element. Corporate communication is the third most important image determinant. With the developing technology, all kinds of communication facilities that banks will provide to their target audiences will positively reflect on the corporate image of banks. Visual identity also ranks fourth as another important factor. The elements such as heating, lighting, logo, personnel clothes, visual guidance signs and housekeeping of the banks were also considered important by the participants. In this respect, the fact that banks attach importance to visual identity elements will contribute positively to their corporate image. Participants also attach importance to the corporate social responsibility activities of the banks that take into consideration the social benefit. It can be stated that such activities will positively reflect on the image of banks in terms of creating corporate belonging and loyalty.

The participants were asked what medium is they received the most news from the banks. According to the answers given for this item, internet was considered as the most important medium. The fact that newspapers and magazines took the last place among the news channels is a reasonable result. Internet banking ranks first among the participants' ways of receiving services from banks. However, the service procurement directly from the ATM was second. In this respect, it should be stated that the participants prefer internet banking as an opportunity of new communication technologies and that a significant proportion of the participants continue to receive services by going directly to the bank ATMs. In this respect, the fact that bank ATMs are equipped with more modern facilities may contribute to the bank's image.

Participants in the 18-28 age group give more attention to security, corporate communication and corporate social responsibility factors than other age groups. Participants, who are at university level, give more importance the factors of security, corporate communication and corporate social responsibility. Participants with a monthly average expenditure of less than 2020 TL give more importance corporate communication and corporate social responsibility factors than participants with other expenditure. Participants with credit cards consider more importantly the items related with security and corporate social responsibility activities more important than those without credit cards. Participants receiving banking services by internet banking, mobile banking and ATM give more attention to the security factor than the others who take banking services going directly to the bank. As a result, participants in the 18-25 age group, most of them university students, who have credit cards and who receive online 
banking services, give more importance to the security factor in bank preferences. This implies that banks should pay more attention to the security factor in order to make their corporate image more positive. For this reason, the most important finding and suggestion of this study is that the banks should carry out more trustworthy practices to their target audiences with public relations activities. This would be possible through public relations policies covering corporate communication, corporate behavior, visual identity and corporate social responsibility practices.

Keywords: Image, Corporate Image, Public Relations, Banks' Image. 
